\title{
Restrictive Practices in the Pharmaceutical Industry: Reverse Payment Agreements Seeking for a Balance between Intellectual Property and Competition Law
}

\author{
This article was published in the ICC Global Antitrust Review Issue 5, 2012
}

\author{
Olga Gurgula*
}

Reverse payment agreements have attracted the close attention of competition authorities as they are suspected to be the fundamental reason for encumbering competition in the pharmaceutical sector. For more than a decade the U.S. competition and judicial authorities have been scrutinising them, developing specific approaches suitable for their assessment. However, once the practice was deemed to be settled, the Third Circuit questioned this practice employing the new test. In the EU this type of agreement was not in focus until recently, therefore no relevant case law has developed whatsoever. Such uncertainty regarding the possible further developments in the assessment of reverse payment agreements is detrimental to the pharmaceutical industry, as it hinders companies' ability to adopt their business strategies without the fear of triggering antitrust liability. This article will examine the current status of the reverse payment agreements in both jurisdictions, analyse the application of article 101 TFEU and Section 1 of the Sherman Act along with other relevant legislative provisions, the applied tests and approaches, and specific examples of the agreements decided by the U.S. courts. Such a discussion pursues the practical goal of expanding understanding of what constitutes permitted behaviour for pharmaceutical companies when concluding this type of agreement with a view to avoiding antitrust liability.

\section{Introduction}

Intellectual property is no longer the arcane domain of intellectual property lawyers. ${ }^{1}$ It is the most valuable corporate asset which a company may possess, and a powerful weapon against its competitors. Increased understanding of the importance of intellectual property rights has advanced their protection and exploitation to a new level. As businesses have developed a greater understanding of the value of their intangible assets, they have not only pursued more rigorous enforcement policies; they have also

Research associate \& PhD candidate at Queen Mary University of London, LLM (QMUL), Ukrainian qualified lawyer Carlos M Correa, Abdulqawi A. Yusuf, Intellectual Property and International Trade: The TRIPS Agreement (Kluwer Law International, The Netherlands 2008) 150. 
invented more imaginative commercial strategies to gain and retain market share using their intellectual property. ${ }^{2}$

As long as such practices facilitate robust competition, they are welcomed and encouraged. However, some strategies have triggered the concern of competition authorities. Where intellectual property rights are used to restrict competition significantly and impose barriers to market entry, intervention of competition law is likely.

As one of the sectors most important to public health, the pharmaceutical industry has always warranted the close attention of competition authorities. Pharmaceutical companies rely heavily on intellectual property to protect their inventions and recoup their investment. It is also seen as the necessary incentive to advance innovation. Pharmaceutical companies therefore make great efforts to protect intellectual property rights, their main tool to ensure a large market share and to exclude competitors from the market for as long as their intellectual property allows them.

Recently, the pharmaceutical industry has undergone significant changes: various "blockbuster" medicines, which account for a substantial part of the sales and profits of large pharmaceutical companies, have lost patent protection, with more to follow in the coming years. ${ }^{3}$ This shift has forced pharmaceutical companies to develop new and reinforce current business practices using their intellectual property rights to retain their market shares.

However, not every practice is welcomed by the competition authorities. A number of new commercial practices used by pharmaceutical companies have been prohibited as exclusionary or exploitive abuses under the competition rules. The AstraZeneca case,${ }^{4}$ for instance, raises the question of when a misuse of the patent process violates Article 102 TFEU. ${ }^{5}$

Other practices have attracted the attention of competition authorities for being the suspected reason for the delay or blocking of generic drug competition. ${ }^{6}$ Such practices include patent settlement agreements concluded between originator companies and generic companies in the context of patent disputes and opposition procedures or litigation where no final adjudication has been handed down. ${ }^{7}$

Certainly, not all patent settlement agreements are deemed illegal. Some are recognised as perfectly legal and even pro-competitive. ${ }^{8}$ Nevertheless, some of these agreements have triggered a flame debate as to their conformity within antitrust law. A main concern among competition authorities are so called reverse payment agreements, in which the originator company pays the generic company for staying off the market. Despite mutual concerns that this type of agreement may raise competition problems, there is no agreement about which of them should be considered illegal and violative of the competition

Steven Anderman and Ariel Ezrachi, Intellectual Property and Competition Law: New Frontiers (Oxford University Press 2011) 6.

3 European Commission, 'Executive Summary of the Pharmaceutical Sector Inquiry Report' (8 July 2009) <http://ec.europa.eu/competition/sectors/pharmaceuticals/inquiry-/communication_en.pdf> accessed 6 August 2012 (Executive Summary).

Anderman (n 2) 8 .

Among such practices, the European Commission defines patent filing strategies, patent related exchanges and litigation, oppositions and appeals, life cycle strategies for second generation products. See Executive Summary (n 3) 3.

7 European Commission, '3rd Report on the Monitoring of Patent Settlements (period: January-December 2011)' (25 July 2012) <http://ec.europa.eu/competition/sectors-/pharmaceuticals/inquiry/patent_settlements_report3_en.pdf> accessed 6August 2012 ( $3^{\text {rd }}$ Monitoring Report).

8 European Commission, 'Pharmaceutical Sector Inquiry Final Report' (8 July 2009) <http://ec.europa.eu/competition/sectors/pharmaceuticals/inquiry/staff_working_paper_part1.pdf> accessed 5 August 2012 (Pharmaceutical Sector Inquiry) 255. 
law and which may be allowed. In addition, there is no agreement as to which evaluative approach to take when considering such disputes.

This article will review the patent settlement agreements under different regimes, including those of the EU and the U.S. This review starts by considering the general background of patent settlement agreements and their types. Then, turning to the U.S. and the EU legal frameworks regarding marketing authorisation underpinning the incentive for pharmaceutical companies to conclude this type of agreement, as well as the competition law provisions of article 101 TFEU and Section 1 of the Sherman Act, it further examines the respective positions of the FTC and the EU Commission regarding the patent settlement agreements.

It will further detail the U.S. courts' specific approaches to evaluating this type of agreement. On the basis of relevant U.S. case law, this article will extract general rules applied by the courts in their judgements. Finally, it will consider specific examples of both lawful and unlawful reverse payment agreements as decided by the courts and will explore whether the differences between the tests applied by the U.S. courts lead to different outcomes for these agreements. It will also examine the most recent decision of the US Court of Appeal for the Third Circuit and the impact it has on the previous case law regarding the reverse payment agreements. It will further discuss the possibility to apply the US tests for the evaluation of the reverse payment agreements to the EU realia considering some differences in the legal framework of these two regimes and will suggest the possible way the reverse payment agreements evaluation under the EU legislation and applying the EU competition law doctrines.

Having discussed and analysed the legislative frameworks, competition authorities' and courts' respective positions toward the patent settlement agreements, and having examined examples of the patent settlement agreements, this article will finish with recommendations regarding the development of a coherent approach to the reverse payment agreements and possible submission of this type of disputes to the jurisdiction of the European Patent Court (EPC). This article also advices which provisions to avoid while negotiating patent settlement agreements in order not to trigger competition concerns. It is hoped that such analysis can offer a practical approach toward understanding what comprises permitted behaviour for pharmaceutical companies when concluding this type of agreement, to avoid antitrust liability.

\section{Patent Settlement Agreements and Types of Reverse Payment Agreements}

\subsection{Patent Settlement Agreements: General Considerations}

Parties may opt to settle a dispute in or out of court to save time and money rather than pursuing the disagreement until the final court decision, which will likely prove unsatisfactory to at least one of the parties. Patent disputes settlements are no exception, as patent litigation is typically lengthy and extremely costly. ${ }^{9}$ The pharmaceutical industry in particular has recently favoured this type of agreement, where the patent is considered a primary corporate asset which the patent holder vigourously protects and which competitors target.

When a patent litigation between brand-name ${ }^{10}$ and generic pharmaceutical companies occurs, it typically involves determining whether the relevant patents are valid and have been infringed. For the

\footnotetext{
$9 \quad$ Pharmaceutical Sector Inquiry (n 8) (originator companies paid, on average, $€ 230,000$ in legal fees per case in a single Member State. The highest amount of legal fees is paid in the UK, with an average of $€ 993,000$ per litigation, followed by the Netherlands and France, approximately half that in the UK, and the lowest in Germany and Austria (€ 76,000 and $€ 46,000)$ para 659 .

10 According to the Federal Food, Drug, and Cosmetic Act the term 'brand name drug company' means the party which holds the approved application (...) for a brand name drug which is a listed drug in an ANDA, or a party which owns
} 
brand-name drug company to prevail, it must successfully defend the validity of its patents and show that the generic's product would infringe those patents. ${ }^{11}$ For the generic company to succeed, it must prove that the patent is invalid or unenforceable and/or that its generic drug does not infringe the patent. ${ }^{12}$ Such disputes are extremely complex and demand enormous effort from both parties. Therefore, given the high costs of patent litigation and the potential uncertainty of the case outcome, brand-name and generic companies may wish to settle a dispute before a court decides on the merits. This trend is evidenced by the rapidly growing number of patent settlements during the last few years. ${ }^{13}$

Such settlements do not necessarily raise competition law concerns. The parties may agree that the generic company may start marketing at some point before the patent expires, but not as soon as it expects through the litigation. ${ }^{14}$ This agreement will most likely reflect the parties' beliefs on the likelihood of success of their legal positions in a dispute. ${ }^{15}$ Settlements which contain no other specific provisions normally do not raise competition concerns.

However, particular types of patent settlement agreements have attracted scrutiny from competition authorities. The so-called 'reverse payment', 'pay-for-delay' or 'exclusionary payments' settlement, wherein some kind of consideration flows from the originator company to the generic company in exchange for the promise by the latter to refrain from entering the market, has sparked doubts about its conformity with competition law principles. The FTC launched a campaign against this type of agreements a decade ago, and the EU Commission and some other national competition authorities have made them a recent focus.

The authorities' main concern is that the pharmaceutical brand name company uses its monopoly profits to pay the generic company to stay out of the market, thus eliminating its direct competitor. This behaviour leads to decreased competition in the pharmaceutical sector and so harms consumers, who do not receive cheaper generic version of the drug as soon as they could have done with the generic company's entry on the market. On the other hand, the proponents of the reverse payment agreements argue that these settlement agreements benefit the public in ending the costly litigation. ${ }^{16}$ As a result, pharmaceutical companies may invest the saved resources into further research for new drugs, and save time and effort on the part of the courts, patent offices and competition authorities to decide the matter, which also has positive public interests. ${ }^{17}$

\subsection{Specific Patent Settlement Agreements: Reverse Payment Agreements and Their Types}

Although some differences exist between the types of reverse payment agreements in the U.S. and the EU, one can highlight certain common provisions used by pharmaceutical companies when settling

a patent for which information is submitted for such drug (..) (Medicare Prescription Drug, Improvement, and Modernization Act of 2003 (n 41) Sec. 1111). The EU equivalent of this term is 'Originator company'.

Federal Trade Commission Staff Study, 'Pay-for-Delay: How Drug Company Pay-Offs Cost Consumers Billions' (January 2010) <http://www.ftc.gov/os/2010/01/100112 payfordelayrpt.pdf> accessed 6 August 2012, 3 (FTC Payfor-Delay Study).

12 ibid.

13 3rd Monitoring Report (n 7) 6 (from 12 patent settlement agreements in 2000 to 120 in 2011).

$14 \quad$ FTC Pay-for-Delay Study (n 11) 3.

15 Federal Trade Commission Report, ‘Authorized Generic Drugs: Short-Term Effects and Long-Term Impact' (August 2011) < http://www.ftc.gov/os/2011/08/2011-genericdrugreport.pdf > accessed 6 August 2012, 140 (FTC Authorized Generic Drugs Report).

16 Pharmaceutical Sector Inquiry (n 8) 255.

17 3rd Monitoring Report (n 7) 2. 
their disputes, based on FTC and EU Commission findings. ${ }^{18}$ The main provisions which raise competition concerns in this type of agreement are whether an agreement contains (i) limitation/restriction on market entry by the generic company and (ii) value transfer from the originator to the generic company. ${ }^{19}$

The value transfer from the originator company to the generic company may take different forms, including:

- a plain monetary transfer from originator to generic company;

- non-monetary benefits from originator to generic company, which may include, inter alia: the originator company's granting a licence to the generic company to manufacture branded product; ${ }^{20}$ entering into the supply/distribution agreement with the generic company; ${ }^{21}$ entering into co-marketing and co-promotion agreements; a promise by the originator not to compete with the generic using its authorised generic (AGs). ${ }^{22}$

The generic company's restrictions on market entry also vary. The parties may agree that the generic company will enter the market before, upon or after the patent expires.

Despite these provisions in reverse payment agreements have raised competition concerns it will be seen in section 4 of this article that not all of these agreements have been held as unlawful.

\section{Legal Framework}

\subsection{Legal Framework Regarding Marketing Authorisation in the U.S. and the EU}

When discussing reverse payment agreements, one must understand the legal basis which creates incentives for generic companies to challenge a patent and for originators to protect it with a claim of patent infringement. Another important factor which requires understanding of the legal framework is that, whilst significant similarities exist between settlement agreements in the EU and the U.S., there are also some differences which result partly from the different regulatory frameworks. ${ }^{23}$

18 See Pharmaceutical Sector Inquiry (n 8), 3rd Monitoring Report (n 7), FTC Pay-for-Delay Study (n 11), FTC Authorized Generic Drugs Report (n 15).

19 Pharmaceutical Sector Inquiry (n 8).270.

203 3rd Monitoring Report (n 7) 3. 'A licence granted by the originator company allowing market presence of the generic company is also categorised as limiting generic entry, because the generic company cannot enter the market with its own product or it cannot set the conditions for the commercialisation of its product freely.' (internal references are omitted) ibid.

21 ibid. 'The same logic applies to patent settlement agreements in which the parties agree that the generic company will be a distributor of the originator product concerned or if the generic company will source its supplies of the active pharmaceutical ingredient (API) from the originator company.' ibid.

22 FTC Authorized Generic Drugs Report (n 15). 'The AGs are pharmaceutical products that are approved as brand-name drugs but marketed as generic drugs. AGs do not bear the brand-name or trademark of the brand-name drug or manufacturer, but the brand-name and AG products are manufactured to the brand's specifications.' ibid. This form of compensation occurs when the brand-name company agrees not to launch its AG during the first-filer's 180-day exclusivity period, in exchange for the first-filer's agreement to delay its market entry.

23 Pharmaceutical Sector Inquiry (n 8) 290. '(...) [i]n the USA, the first generic company to file a paragraph-IV certification is explicitly rewarded by the legislator, whilst in the EU the first to market enjoys no statutory period during which he is protected against market entry of a second, third or subsequent generic company.' ibid. This difference has created a specific type of value transfer - authorised generics as a bargaining asset to induce a generic company to refrain from entering the market. See FTC Authorized Generic Drugs Report (n 15) n 21. This value 


\subsubsection{U.S. legislation}

To start marketing a drug in the U.S., a pharmaceutical company must first apply for approval to the Food and Drug Administration (FDA) under the Federal Food Drug and Cosmetic Act. ${ }^{24}$ A brand-name company obtains FDA approval for the new drug through a New Drug Application (NDA) and must prove that its product is safe and effective. ${ }^{25}$

\section{(a) Hatch-Waxman Act}

The Hatch-Waxman Act, ${ }^{26}$ enacted in 1984 , and amended in $2003,{ }^{27}$ provides alternative ways for generic companies to obtain FDA approval for their products. The main purpose for introducing the Hatch-Waxman Amendments was to encourage generic companies to enter the market at an earlier stage, and thus facilitate competition with a brand-name $\operatorname{drug}^{28}$ which would 'make available more low cost generic drugs ${ }^{29}$ for consumers. The Act provides an accelerated process for submitting an 'Abbreviated New Drug Application' (ANDA) to the FDA to gain approval for a drug which is shown to be a bioequivalent to a new drug previously approved by the FDA.$^{30}$ Thus, in order to prove the safety and efficacy of the generic medicine a generic company now may to rely on the clinical data first submitted by the brand-name pharmaceutical company. ${ }^{31}$

If the generic company wants to enter the market before the patent expiration for the brand-name drug, it may apply for 'Paragraph IV' ANDA certifying that the 'patent is invalid or will not be infringed by the manufacture, use, or sale of the new drug for which the application is submitted. ${ }^{32}$ The company must also include in the application a statement that it will give notice of its certification to each owner of the patent which is the subject of certification, including a detailed statement of the factual and legal basis of the applicant's opinion that the patent is invalid or will not be infringed. ${ }^{33}$

Paragraph IV certification constitutes a technical act of infringement. ${ }^{34}$ It empowers the patent holder brand-name drug company to bring an action for a patent infringement within 45 days of the received notice. ${ }^{35}$ The approval will be given immediately upon the expiration of 45 days if no such patent

transfer is typical for the U.S. market, but not the EU, as the lack of exclusivity period for the first filer offers no bargaining power to the originator company.

21 U.S.C. § 301, 21 U.S.C. § 355(b).

21 U.S.C. $\S 355(b),(c)$.

Codified as amended at 21 U.S.C. $\S 355$ and 35 U.S.C. $\S ~ 156$ and 271, 282.

Amended as part of the Medicare Prescription Drug, Improvement, and Modernisation Act of 2003.

FTC Pay-for-Delay Study (n 11) 3, See also Joseph J. Jacobi, 'Reconsidering the Antitrust Implications of Settlement in ANDA Litigation' [2010] SRR Journal http://www.srr.com/article/reconsidering-antitrust-implications-settlementandalitigation accessed 6 August 2012.

H.R. REP. NO. 98-857, at 14 (1984), as reprinted in 1984 U.S.C.C.A.N. 2647. (H.R. REP. NO. 98-857).

21 U.S.C. § 355(j). See FTC Authorized Generic Drugs Report (n 15) 3.

FTC Authorized Generic Drugs Report (n 15) 3.

21 U.S.C. § 355(j)(2)(A)(vii)(IV).

21 U.S.C. $\$ 355(\mathrm{j})(2)(\mathrm{B})$.

35 U.S.C. $\S 271(\mathrm{e})(2)(\mathrm{A})$.

21 U.S.C. $\S 355(\mathrm{j})(5)(\mathrm{B})(\mathrm{iii})$. 
infringement action is brought within that period. ${ }^{36}$ However, if the brand-name company does file a patent infringement suit within the stated period, the approval shall be made effective upon the expiration of the30-month period beginning on the date of the receipt of the notice or upon a favourable decision of the court - whichever comes earlier. ${ }^{37}$

Once the earliest event occurs, the FDA may authorise the marketing of the generic drug, and the first applicant of Paragraph IV ANDA becomes entitled to 180-day exclusivity period. ${ }^{38}$ This exclusivity period means that subsequent ANDA applications will become effective only upon the expiration of this period, ${ }^{39}$ which effectively protects the first to file generic company from generic competition during this period. It thereby provides an incentive to challenge patents of brand-name pharmaceutical companies seeking to enter the market prior to patent expiration. ${ }^{40}$

\section{(b) Medicare Prescription Drug, Improvement, and Modernization Act of 2003}

Following FTC recommendations, ${ }^{41}$ Congress passed the Medicare Prescription Drug, Improvement, and Modernization Act of $2003^{42}$ to address irregularities created by the Hatch-Waxman Amendments. ${ }^{43}$ The Act includes only one 30-month stay per ANDA, ${ }^{44}$ forfeiture of the 180-day exclusivity period under certain circumstances ${ }^{45}$ and, most important, the stipulation that agreements between ANDA applicants or between ANDA applicants and NDA holders must be filed with the Department of Justice and the FTC within 10 days of execution. ${ }^{46}$

\subsubsection{EU Legislation}

In the EU, as in the U.S., a pharmaceutical company must obtain marketing authorisation (MA) for a drug to be placed on the market. ${ }^{47}$ Two types of authorisation exist: national authorisation, which is issued by the competent authorities of the EU Member States and is effective on its territory, ${ }^{48}$ and community authorisation, which is issued by the European Commission on the basis of the centralised procedure and covers the territory of the EU. ${ }^{49}$ Regulation (EC) No $726 / 2004^{50}$ governs the centralised

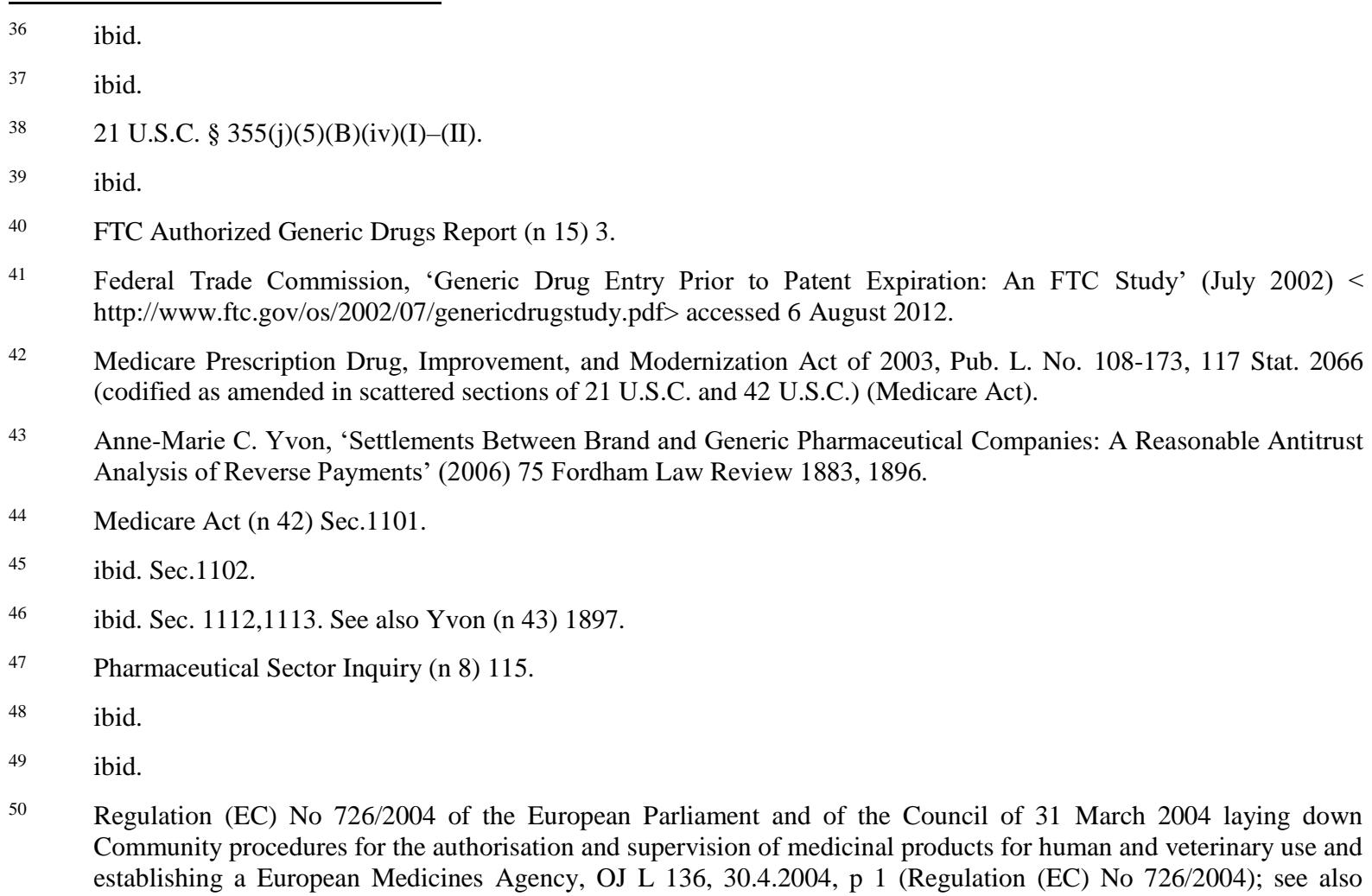


procedure, which offers a single application, a single evaluation, a single authorisation and the right to market medicinal product in all EU Member States. ${ }^{51}$

The generic company may receive marketing authorisation without providing its own pre-clinical tests and clinical trials if it can show that its medicine is a generic version of a previously approved drug. ${ }^{52}$ The authority relies on the tests and trials for the already approved drug, submitted by originator company, but only after the expiration of the data exclusivity period which protects the data relating to the approved drug. ${ }^{53}$

Before 2004, the EU did not regulate product development by the generic company whilst the originator's patent was still alive; each country decided this issue at the national level. ${ }^{54}$ The legal uncertainty about whether the research for the marketing authorisation before the patent's expiration amounted to patent infringement forced generic companies to wait for patent expiration to carry out their product development and related testing in countries where the basic patent had already expired or where such protection did not exist. ${ }^{55}$

The Directive 2004/27/EC was introduced to eliminate this uncertainly. ${ }^{56}$ The so-called 'Bolar' provision was designed to give generic companies an exemption for pre-marketing testing, to bring EU legislation closer to the U.S. ${ }^{57}$ This provision creates a safe harbour for certain tests and studies whilst the reference product is still patent-protected in the EU so as to enable the generic producer to apply for marketing authorisation once the period of data exclusivity granted to the holder of the original MA has elapsed. ${ }^{58}$ After the implementation of this Directive, therefore, a generic company can obtain market authorisation for a bioequivalent drug before the patent has expired, which allows the company to start marketing its drug immediately after the patent expires..$^{59}$

\subsubsection{Differences between the U.S. and EU Legal Frameworks}

Despite general similarities between the U.S. and EU legal frameworks regarding drug-marketing authorisations, certain differences have led to the evolution of specific provisions of the reverse payment agreements pertaining to the particularities of the legal provisions in the respective jurisdictions.

Directive 2001/83/EC of the European Parliament and of the Council of 6 November 2001 on the Community Code relating to medicinal products for human use, OJ L 311, 28.11.2001, p

67. (Directive 2001/83/EC).

$51 \quad$ Pharmaceutical Sector Inquiry (n 8) 118.

52 Directive 2001/83/EC (n 50) Art. 10.

53 ibid. See also Pharmaceutical Sector Inquiry (n 8) 119

54 Pharmaceutical Sector Inquiry (n 8) 122. See also Kristof Roox, 'The Bolar provision: a safe harbour in Europe for biosimilars', $\quad$ (2006) 172 EURAlex < http://www.crowell.com/documents/DOCASSOCFKTYPE_ARTICLES_614.pdf> accessed 6 August 2012.

55 Pharmaceutical Sector Inquiry (n 8) 123. See Roox (n 54). 'In the US, for example, the US Court of Appeals initially ruled in the case of Roche $v$. Bolar that the experimental use of a drug for the purposes of obtaining regulatory approval for a generic version of a patented pharmaceutical product constituted a patent infringement. Following this case, US patent law was amended to include an exemption to permit such activities'. See also Aria Joze Zomorodian, 'Settlement Agreements in Patent Litigation; American lessons for a European context' (Master thesis, Lund University 2012) 23.

Directive 2004/27/EC the European Parliament and of the Council of 31 March 2004 amending Directive 2001/83/EC on the Community code relating to medicinal products for human use OJ L 136, 30.4.2004, p 34. (Directive 2004/27/EC).

$57 \quad$ Roox (n 54) 19.

58 Pharmaceutical Sector Inquiry (n 8) 123-124.

$59 \quad$ Zomorodian (n 55) 23. 
Although, the implementation of Bolar provisions brought EU regulation closer to the U.S, the latter legislation has also expanded the possibilities of market entry by generic companies by introducing the so-called 'Paragraph IV' certification. This legislation enables generic companies to enter the market before a patent expires, an early entry encouraged by the 180-day exclusivity period granted to the firstto-file generic company. These provisions have no equivalent in EU law. Such provisions in U.S. legislation have triggered new kinds of reverse payment agreements which are not specific to EU law. ${ }^{60}$ This is the case of brand-name drug companies, instead of paying the generic companies for their promise not to enter the market, agree not to launch their authorised generics in competition with the approved generic drug during the 180 -day exclusivity period. ${ }^{61}$

\section{2. $\quad U . S$. and $E U$ competition rules applicable to the reverse payment agreements}

\subsubsection{U.S. antitrust rules}

Section 1 of the Sherman Act prohibits '[e]very contract, combination (...) or conspiracy, in restraint of trade or commerce among the several States, or with foreign nations' ${ }^{62}$

\subsubsection{EU competition rules}

Historically, EU competition law treated patent settlement agreements like any other agreement. ${ }^{63} \mathrm{As}$ defined by the Court of Justice of the European Union (CJEU) in the context of 'no-challenge' clauses:

In its prohibition of certain 'agreements' between undertakings, Article [101 (1) TFEU] ${ }^{64}$ makes no distinction between agreements whose purpose is to put an end to litigation and those concluded with other aims in mind. ${ }^{65}$

The Commission scrutinises this kind of agreement under article 101 of the Treaty on the Functioning of the European Union (TFEU), which prohibits agreements and concerted practices which may affect trade and prevent or restrict competition.

Unlike U.S. legislation, Section 1 of the Sherman Act, article 101 TFEU contains paragraph 3, which provides for individual exemptions to the main prohibitions set in paragraph 1, subject to specified criteria. Thus, an agreement may be exempted provided that it:

contributes to improving the production or distribution of goods or to promoting technical or economic progress, while allowing consumers a fair share of the resulting benefit, and which does not: (a) impose on the undertakings concerned restrictions which are not indispensable to the attainment of these objectives; (b) afford such undertakings the possibility of eliminating competition in respect of a substantial part of the products in question. ${ }^{66}$

\footnotetext{
$60 \quad$ Pharmaceutical Sector Inquiry (n 8) 291.

$61 \quad$ FTC Authorized Generic Drugs Report (n 15) 141.

6215 U.S.C. $\$ 1$.

63 Sean-Paul Brankin, Patent settlements and competition law: where is the European Commission going?' (2009) 5(1) Journal of Intellectual Property Law \& Practice 23, 23.

64 Article 101 (1) of the Treaty on the Functioning of the European Union (TFEU).

65 Case 65/86 Bayer AG v Maschinenmfabrik Hennecke GmbH \& Heinz Sullhoftr [1988] ECR-5249, para 15.

66 Article 101 (3) TFEU.
} 
In addition, several block exemption regulations give guidance to undertakings on which agreements will be exempted. ${ }^{67}$ Of particular interest to this article is the Technology Transfer Block Exemption Regulation (TTBER), which addresses competition concerns arising, inter alia, due to patent licensing agreements. ${ }^{68}$ The TTBER recognises that technology transfer agreements usually improve economic efficiency, are pro-competitive and give rise to competition concerns only when the undertakings have a high level of market power and agree to incorporate particularly damaging restrictions within the agreement. ${ }^{69}$

In its Guidelines to the TTBER, ${ }^{70}$ the European Commission acknowledges that the licence agreements 'in the context of settlement agreements and non-assertion agreements is not as such restrictive of competition since it allows the parties to exploit their technologies post agreement. ${ }^{71}$ The Commission indicates, however, that 'the individual terms and conditions of such agreements may be caught by Article [101](1) [TFEU]. ${ }^{72}$ The Commission defines that ' $[\mathrm{w}]$ here the parties have a significant degree of market power and the agreement imposes restrictions that clearly go beyond what is required in order to unblock, the agreement is likely to be caught by Article [101]. ${ }^{73}$ The Commission does not explain what is meant by 'beyond the unblocking', but one may argue that, for instance, the restrictions relating to other intellectual property rights which are not in dispute may well be deemed as going beyond that needed to unblock. ${ }^{74}$

\section{Competition Authorities' Positions on Reverse Payment Agreements}

\subsection{FTC Position}

For more than a decade, the FTC has been straggling with certain types of patent settlement agreements where the brand-name companies pay generics to delay entry. ${ }^{75}$ The FTC contends that, although branded pharmaceutical manufacturers and their generic competitors tend to view reverse payment settlements favourably, consumers may suffer as 'they miss out on generic prices that can be as much as 90 per cent less than brand prices. ${ }^{76}$ According to FTC staff analysis published in January 2010, exclusion payment settlements cost consumers $\$ 3.5$ billion per year. ${ }^{77}$

The FTC's main concern regarding reverse payments is that the patent holder is using part of the profits from its patent monopoly to buy off the entry of its competitor. ${ }^{78}$ Thus, the FTC sees such agreements

\footnotetext{
67 Catherine Colston, Jonathan Galloway, Modern Intellectual Property Law (3rd edn, Routledge 2009) 25.

68 Commission Regulation (EC) No 772/2004 of 27 April 2004 on the application of Article 81(3) of the Treaty to categories of technology transfer agreements, OJ L 123, 27.4.2004, 11 (TTBER), see also Colston (n 67) 26.

69 TTBER (n 68) recitals para 5, see also Colston (n 67) 26.

70 Commission Notice, 'Guidelines on the application of Article 81 of the EC Treaty [now Art. 101 TFEU) to technology transfer agreements' OJ [2004] C 101/02 (Technology Transfer Guidelines).

71 ibid, para 204.

72 ibid.

73 ibid, para 207.

$74 \quad$ Anderman (n 2) 283.

75 FTC Authorized Generic Drugs Report (n 15) i.

$76 \quad$ FTC Pay-for-Delay Study (n 11) 1.

$77 \quad$ FTC Pay-for-Delay Study (n 11) 2.

$78 \quad$ Brankin (n 63) 24.
} 
as a violation of antitrust law, namely Section 1 of the Sherman Act. The FTC argues that such settlements may raise serious competition concerns when they involve compensation from the brandname company to the generic company to delay generic entry beyond the time of a simple compromise date. ${ }^{79}$ According to the FTC position, such settlements 'thwart the goal of the Hatch-Waxman Amendments to encourage generic companies to challenge questionable patents and promptly 'make available more low cost generic drugs', while simultaneously protecting legitimate patent claims covering innovator drugs. ${ }^{80}$ The FTC has challenged a number of these agreements, and is lobbying for them to be recognised as illegal at the legislative level. ${ }^{81}$

\subsection{European Commission Position}

Unlike the U.S., in Europe patent settlement agreements have neither raised significant interest by the European Commission previously ${ }^{82}$ nor have they been the subject of consideration before the CJEU.

However, inspired by its U.S. counterpart and following the AstraZeneca case ${ }^{83}$ the EU Commission has launched intensive monitoring of competition in the pharmaceutical sector ${ }^{84}$ Its Executive Summary of the Pharmaceutical Inquiry Report emphasises ' $[t]$ he importance of a well-functioning pharmaceutical sector and the presence of certain indications that competition in the pharmaceutical market in the European Union might not be working well. ${ }^{85}$ The inquiry aimed ' $[\mathrm{t}] \mathrm{o}$ examine the reasons for observed delays in the entry of generic medicines to the market and the apparent decline in innovation as measured by the number of new medicines coming to the market. ${ }^{, 86}$ The inquiry sought inter alia to examine practices which '[c]ompanies may use to block or delay generic competition. ${ }^{87}$

The inquiry identifies patent settlement agreements among such practices which delay or block generic entry. ${ }^{88}$ The European Commission sees agreements which limit market entry of the generic and include a value transfer from the originator company to a generic company as potentially anticompetitive ${ }^{89}$ The Commission also deems potentially problematic those agreements which include restrictions beyond the exclusionary zone of the patent, meaning that they reach beyond its geographic scope, its period of protection or its exclusionary scope..$^{90}$ The Commission explains that the reason for this concern

$79 \quad$ FTC Authorized Generic Drugs Report (n 15) 140. The simple compromise date according to the FTC is when "the brand and generic settle the litigation simply by agreeing on a time for generic entry that is prior to patent expiration but later than immediate entry without any compensation.' ibid.

$80 \quad$ FTC Authorized Generic Drugs Report (n 15) 141 citing H.R. REP. NO. 98-857 (n 29).

81 Federal Trade Commission, 'Statement by FTC Chairman Jon Leibowitz Regarding Senate Judiciary Committee Mark-up of Legislation Stopping Illegal Pay-for-Delay Drug Settlements' (07/21/2011) < http://www.ftc.gov/opa/2011/07/pdfmarkup-.shtm> accessed 6 December 2012.

$82 \quad$ Brankin (n 63) 23.

AstraZeneca (n 4), the EU General Court agreed with the Commission's findings of the AstraZeneca's abuse of a dominant market position in the pharmaceutical sector via misusing the regulatory framework to delay the market entry of competing generic products.

Commission Decision of 15 January 2008 initiating an enquiry into the pharmaceutical sector pursuant to Article 17 of Council Regulation (EC) No 1/2003 (Case No COMP/D2/39.514).

85 Executive Summary (n 3).

86 ibid.

87 ibid. 'The scope of the inquiry included companies with $80 \%$ of the relevant turnover in the EU, 43 originator and 27 generic companies, limiting products to medicines for human use within the 27 member states and the time limitation was from 2000 to 2007.' ibid.

$88 \quad$ ibid.

89 ibid.

$90 \quad 3$ rd Monitoring Report (n 7). 
regarding this type of agreements is that such agreements do not relate directly to the IP rights granted by the patents in question. ${ }^{91}$ The Commission also indicates as problematic those agreements which include settlement agreements on a patent which the patent holder knows that it does not meet the patentability criteria. ${ }^{92}$ For instance, a patent may be granted following the provision of incorrect, misleading or incomplete information. ${ }^{93}$ Therefore, the European Commission decided to monitor further the settlements 'with a potential to adversely affect European consumers. ${ }^{94}$ Currently, three Reports in the Monitoring of Patent Settlements were concluded. ${ }^{95}$

Following its inquiry into the pharmaceutical sector and monitoring exercises, the Commission has opened formal antitrust investigations against originator and generic companies suspected of engaging in anticompetitive practices and it has examined their patent settlement agreements. The two major cases concern the brand-name companies Lundbeck and Les Laboratoires Servier.

According to the Commission press release, the Danish company Lundbeck and its four generic competitors were informed of the Commission's objections regarding their settlement agreements concerning Citalopram, an antidepressant. ${ }^{96}$ The Commission has expressed its preliminary view that these agreements aimed to prevent the market entry of cheaper generic medicines in violation of Article 101 TFEU. ${ }^{97}$

According to the Commission, these agreements were concluded when the generic entry became possible after certain Lundbeck's patents had expired. ${ }^{98}$ The agreements contain substantial value transfers from Lundbeck to the generic companies, and resulted in the subsequent refrain by the latter from entering the market. ${ }^{99}$ The value transfers occurred via direct payments from Lundbeck to the generic companies and via the purchase of generic Citalopram stock for destruction or guaranteed profits in a distribution agreement. ${ }^{100}$ The Commission considers that these agreements may have caused substantial consumer harm, as they may have delayed the entry of generic medicine for up to two years. ${ }^{101}$ The price of Citalopram remained high as a result. ${ }^{102}$

\footnotetext{
91 ibid.

92 ibid.

93 ibid.

$94 \quad$ Executive Summary (n 3) 20.

95 European Commission, '1st Report on the Monitoring of Patent Settlements (period: mid 2008-end 2009)' (5 July 2010) <http://ec.europa.eu/competition/sectors/-pharmaceuticals/inquiry/patent_settlements_report1.pdf> accessed 6 August 2012; European Commission, '2nd Report on the Monitoring of Patent Settlements (period: January-December 2010)' (6 July 2011) <http://ec.europa.eu/competition/sectors/pharmaceuticals/inquiry/patent_settlements_report2.pdf> accessed 6 August 2012; $3^{\text {rd }}$ Monitoring Report (n 7).

European Commission Press Release, 'Antitrust: Commission sends Statement of Objections to Lundbeck and others for preventing market entry of generic antidepressant medicine' IP/12/834 (25 July 2012) $<$ http://europa.eu/rapid/pressReleasesAction.do?reference=IP/12/834\&format=HTML\&aged=0\&language=EN\&gui Language $=$ en $>$ accessed 6 August 2012. ibid. 
Another major investigation was launched against the French pharmaceutical company Les Laboratoires Servier. ${ }^{103}$ In its press release on 30 July 2012, ${ }^{104}$ the Commission stated that Servier and its several generic competitors were informed of the Commission's objections against their patent settlement agreements and Servier's acquisition of key competing technologies, which may have delayed the generic entry of the cardiovascular medicine Perindopril. The Commission alleges that Servier unduly protected its market exclusivity by inducing its generic challengers to conclude patent settlements, which the Commission considers a violation of EU competition rules prohibiting restrictive business practices and the abuse of a dominant market position (respectively articles 101 and 102 TFEU). ${ }^{105}$ Additional pending investigations concern Cephalon and Teva ${ }^{106}$ and Johnson \& Johnson and Novartis ${ }^{107}$ for potential violations of the EU competition rules.

\section{U.S. Courts' Developments: Approaches, General Rules and Specific Examples of Reverse Payments Agreements}

\subsection{U.S. Courts'Approaches to Reverse Payment Agreements}

Contrary to the firm position of the FTC regarding the anticompetitive nature of reverse payment agreements, U.S. courts are currently divided as to how to scrutinise such agreements. They were the subject of considerations in several appellate circuits, which have taken different approaches to their evaluations and have arrived at different conclusions. By examining the applied tests developed by the courts, the particular terms of the agreements and the outcome of the cases, we will determine which reverse payment agreements were deemed lawful and which were deemed anticompetitive.

\subsection{1. 'Per Se Illegality' Approach}

This approach was taken by the U.S. Court of Appeal for the Sixth Circuit in the case of 'first impression'. The case involved payment from a brandname company to a generic company in exchange for the promise by the latter to refrain from entering the market even after the FDA's approval. ${ }^{108}$ The Court explained that most restraints are evaluated using a 'rule of reason', other restrains, however, 'are deemed unlawful per se ${ }^{\text {, } 109}$ because they 'have such predictable and pernicious anticompetitive effect,

\footnotetext{
103 European Commission, Memo 'Antitrust: Commission opens formal proceedings against Les Laboratoires Servier and a number of generic pharmaceutical companies' (July 2009) MEMO/09/322 <http://europa.eu/rapid/pressReleasesAction.do?reference=MEMO-/09/322\&format=HTML\&aged=0\&language> accessed 6 July 2012. European Commission Press Release, 'Antitrust: Commission sends Statement of Objections on perindopril to Servier and $\quad$ others' IP/12/835 (30 July 2012$)$ <http://europa.eu/rapid/pressReleasesAction.do?reference=IP/12/835\&format=HTML\&aged=0\&language=EN\&gui Language=en $>$ accessed 6 July 2012. ibid.

European Commission Press Release, 'Antitrust: Commission opens investigation against pharmaceutical companies Cephalon and Teva' IP/11/511 $\quad$ (28 $\quad$ April $<\mathrm{http} / / /$ europa.eu/rapid/pressReleasesAction.do?reference=IP/11/511\&format=HTML\&aged=1\&language=EN\&gui Language $=\mathrm{en}>$ accessed 6 July 2012.

European Commission Press Release, 'Antitrust: Commission opens proceedings against Johnson \& Johnson and Novartis' IP/11/1228 (21 $\quad$ October 2011) $<$ http://europa.eu/rapid/pressReleasesAction.do?reference=IP/11/1228\&format=HTML\&aged=1\&language=EN\&gu iLanguage $=\mathrm{en}>$ accessed 6 July 2012 .

In re Cardizem CD Antitrust Litigation, 332 F.3d 896 (6th Cir. 2003), cert denied, 125 S.Ct. 307 (2004) (Cardizem 6th Cir. 2003).

ibid 906.
} 
and such limited potential for pro-competitive benefit. ${ }^{110}$ It referred to the Supreme Court, which "has identified certain types of restraints as subject to the per se rule. The classic examples are naked, horizontal restraints pertaining to prices or territories.' 111

The Court reiterated that '(...) the virtue/vice of the per se rule is that it allows courts to presume that certain behaviours as a class are anticompetitive without expending judicial resources to evaluate the actual anticompetitive effects or pro-competitive justifications in a particular case. ${ }^{\prime 12}$ Thus, applying this test, the Court rejected any arguments regarding the pro-competitive nature of the agreement and held that the agreement was 'at its core, a horizontal agreement to eliminate competition (...)' and 'a classic example of a per se illegal restraint of trade.'113

\subsection{2. 'Rule of Reason' Approach}

The U.S. Court of Appeal for the Second Circuit used a different approach. ${ }^{114}$ In deciding on the lawfulness of the agreement, the Court applied the 'rule of reason' analysis, which involves a three-step process. ${ }^{115}$ 'First, the plaintiff bears the initial burden of showing that the defendant's conduct 'had an actual adverse effect on competition as a whole in the relevant market'. If the plaintiff satisfies this burden, the burden then shifts to the defendant to offer evidence that its conduct had pro-competitive effects. If the defendant is able to offer such proof, the burden shifts back to the plaintiff who must prove that any legitimate competitive effects could have been achieved through a less restrictive alternative.' 116

The Federal Circuit, agreeing with the Second Circuit regarding the application of this test, explained that the starting point is to define the relevant market and to determine whether the defendants possess market power therein. ${ }^{117}$

To analyse further whether there was 'actual adverse effect on competition', the first step of the 'rule of reason' test, the Second Circuit raised the question of whether reverse payments agreements 'fall within the scope of the patent holder's property rights, or whether such settlements are properly characterized as illegal marketing-sharing agreements. ${ }^{118}$ Approaching this question, the Court referred to the Court's previous decision in another case,${ }^{119}$ stating that the right to enter into such an agreement falls within 'the terms of the exclusionary grant conferred by the branded manufacture's patent'. ${ }^{120}$ It added that, unless the patent was obtained by fraud patent or an enforcement suit is objectively baseless,

\footnotetext{
$110 \quad$ ibid 906 citing Northern Pacific Ry. Co. v. United States, 356 U.S. 1, 5, 78 S.Ct. 514, 2 L.Ed.2d 545 (1958).

$111 \quad$ ibid 907

$112 \quad$ ibid 909.

113 ibid.

$114 \quad$ Ark. Carpenters Health \& Welfare Fund v. Bayer AG (In re Ciprofloxacin Hydrochloride Antitrust Litig.) 604 F.3d 98 (2d Cir. 2010), cert.denied, 131 S.Ct. 1606 (2011) (Cipro 2d Cir. 2010).

115 ibid,104

116 Cipro 2d Cir. 2010 (n 114) 104 citing Capital Imaging Assocs., P.C. v. Mohawk Valley Med. Assocs., Inc., 996 F.2d 537 (2d Cir. 1993).

117 Ark. Carpenters Health \& Welfare Fund v. Bayer AG (In re Ciprofloxacin Hydrochloride Antitrust Litig.), 544 F.3d 1323 (Fed. Cir. 2008), cert. denied, 129 S.Ct. 2828 (2009) (Cipro Fed. Cir. 2008) 1332 citing Geneva Pharms. Tech. Corp. v. Barr Labs.,Inc., 386 F.3d 485, $495-96$ (2d Cir. 2004), and United States v. Visa U.S.A., Inc., 344 F.3d 229, 238 (2d Cir. 2003).

$118 \quad$ Cipro 2d Cir. 2010 (n 114) 104.

119 Joblove v. Barr Labs., Inc. (In re Tamoxifen Citrate Antitrust Litig.), 429 F.3d 370 (2d Cir. 2005), amended by, 466 F.3d 187 (2d Cir. 2006) (Tamoxifen 2d Cir. 2006).

120

Cipro 2d Cir. 2010 (n 114) 105.
} 
'there is no injury to the market cognizable under existing antitrust law, as long as competition is restrained only within the scope of the patent. ${ }^{121}$

The Federal Circuit, applying the same 'rule of reason' test, stated that there was no evidence that the settlement agreements created a bottleneck on challenges to the patent or otherwise restrained competition outside the 'exclusionary zone' of the patent. ${ }^{122}$ Therefore, 'the plaintiffs had failed to demonstrate that the Agreements had an anti-competitive effect on the market for [the drug] beyond that permitted by the patent. ${ }^{123}$ Since the plaintiffs had not provided the facts needed under the first step of this analysis, the Court found it unnecessary to consider the second or third step. ${ }^{124}$

\subsection{3. 'Scope of the Patent' Test}

In deciding on the lawfulness of reverse payment agreements, the Eleventh Circuit preferred a more traditional analysis. It focused on the permissible exclusionary scope under the patent as compared to the exclusions and anticompetitive effects arising out of the agreement. ${ }^{125}$ The court explained that "neither the rule of reason nor the per se analysis is appropriate in this context, ${ }^{, 26}$ as these tests aim to determine whether the agreement had an anticompetitive effect on the market. ${ }^{127}$ However, the Court indicated that 'by its nature patents create an environment of exclusion, and consequently, cripple competition. The anticompetitive effect is already present.' ${ }^{128}$

The Court added, that 'the proper analysis of antitrust liability requires an examination of: (1) the scope of the exclusionary potential of the patent; (2) the extent to which the agreements exceed that scope; and (3) the resulting anticompetitive effects. ${ }^{129}$ When discussing the first step of the test, the court held that an agreement cannot exclude more competition than the patent has the potential to exclude. ${ }^{130}$ Otherwise, the patent holder 'has used the settlement to buy exclusionary rights that are not contained in the patent grant, and those additional rights are vulnerable to antitrust attack. ${ }^{\prime 31}$ Thus, if the anticompetitive effects fall within the scope of the exclusionary potential of the patent, the parties are immune from antitrust liability. ${ }^{132}$ The Court stated that, under the patent, the originator company had the right to exclude the generic companies from the market ${ }^{133}$ and to grant licenses. ${ }^{134}$ Such rights existed until the patent expired, or until the generic manufacturers proved either that the patent was invalid or that their products did not infringe upon the originator's patent. ${ }^{135}$

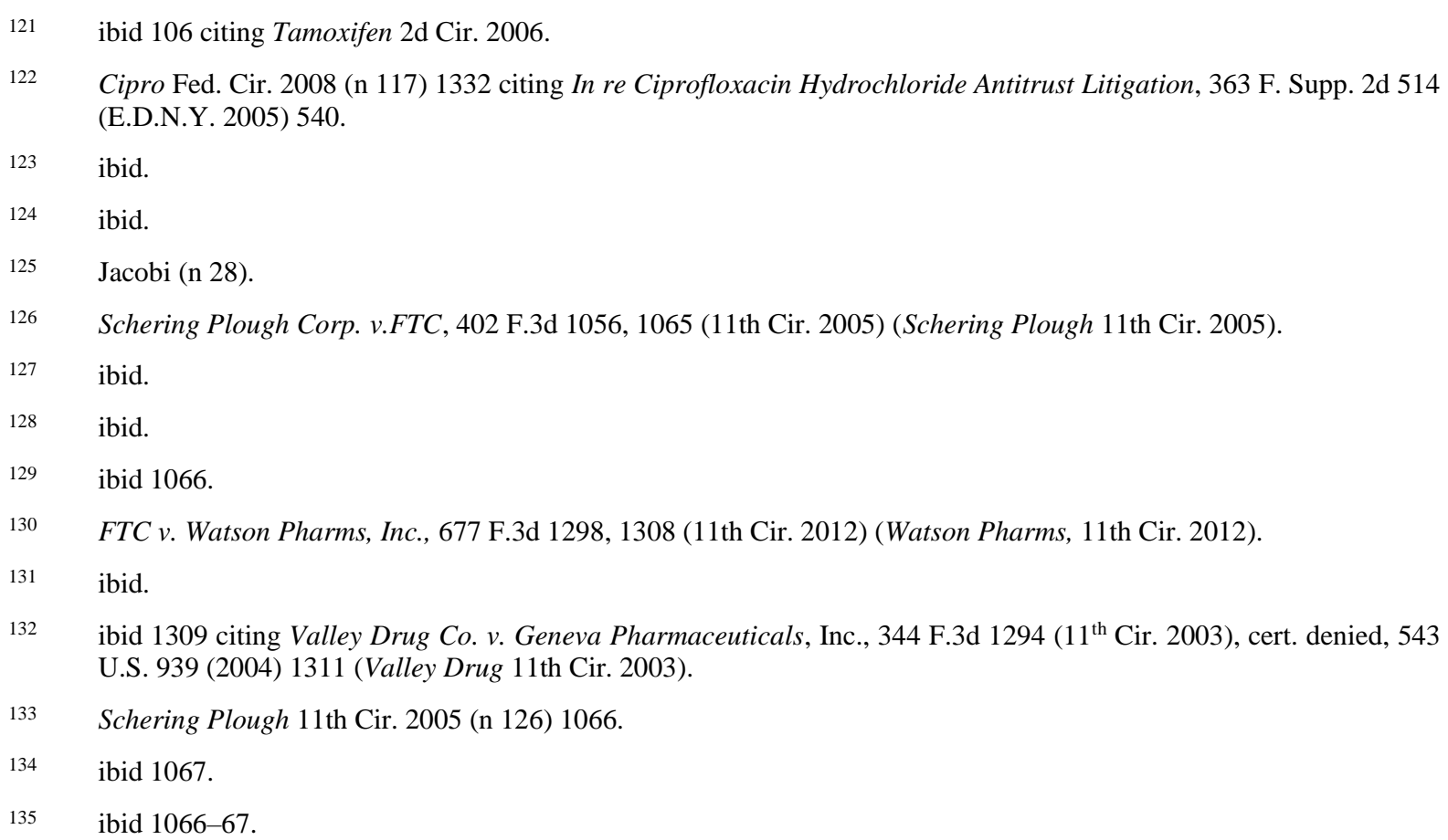


Under the second step of the test, the court analysed whether the settlement extended the originator's exclusionary rights beyond that scope. The court held that, as the settlements permitted generic companies to market their generic drugs several years before the patent's expiration, the competition was excluded for a shorter period than the patent allowed. ${ }^{136}$ As a result, the Court determined that 'the reverse payment settlements did not impermissibly extend the originator's patent monopoly. ${ }^{137}$

The third step of this analysis requires findings about whether the reverse payment agreements were indeed an 'unfair method of competition. ${ }^{138}$ It referred to the Supreme Court, which requires that the effects be actually anticompetitive. ${ }^{139}$ The Court defined that the patent claims covered the restraints at hand and defined this clause as an 'ancillary restraint.' ${ }^{140}$ The Court decreed that, for a condition to be defined as an ancillary, 'an agreement limiting competition must be secondary and collateral to an independent and legitimate transaction. ${ }^{141}$

The court stated that, under the agreement, the scope of the products subject to the specific entry date demonstrates an efficient narrowness and no other products were delayed by these ancillary restraints. ${ }^{142}$ Moreover, the agreement covered the identical reach of the patent. ${ }^{143}$ Therefore, emphasising that the 'general policy of the law is to favour the settlement litigation', ${ }^{144}$ the court concluded that the settlements 'fell well within the protection of the patent and were therefore not illegal'. ${ }^{145}$

\subsubsection{A Quick Look 'Rule of Reason' Analysis}

The Third Circuit used this approach in its most recent decision regarding reverse payment agreements. ${ }^{146}$ Notably, the agreements under review in this Court were already under consideration in the Eleventh Circuit. ${ }^{147}$ Applying the scope of the patent test, the latter declared these agreements lawful and not violative of antitrust law as they did not exceed the scope of the patent.

The Third Circuit, considering the same agreements, disagreed with the Eleventh Circuit. The Court rejected the scope of the patent test and instead applied a quick look rule of reason analysis. ${ }^{148}$ This analysis is based on the economic realities of the agreement in question. ${ }^{149}$ Thus, the Court explained that the very existence of any payment from a brand-name company to a generic patent challenger who agrees to delay its market entry stands as prima facie evidence of an unreasonable restraint of trade. ${ }^{150}$

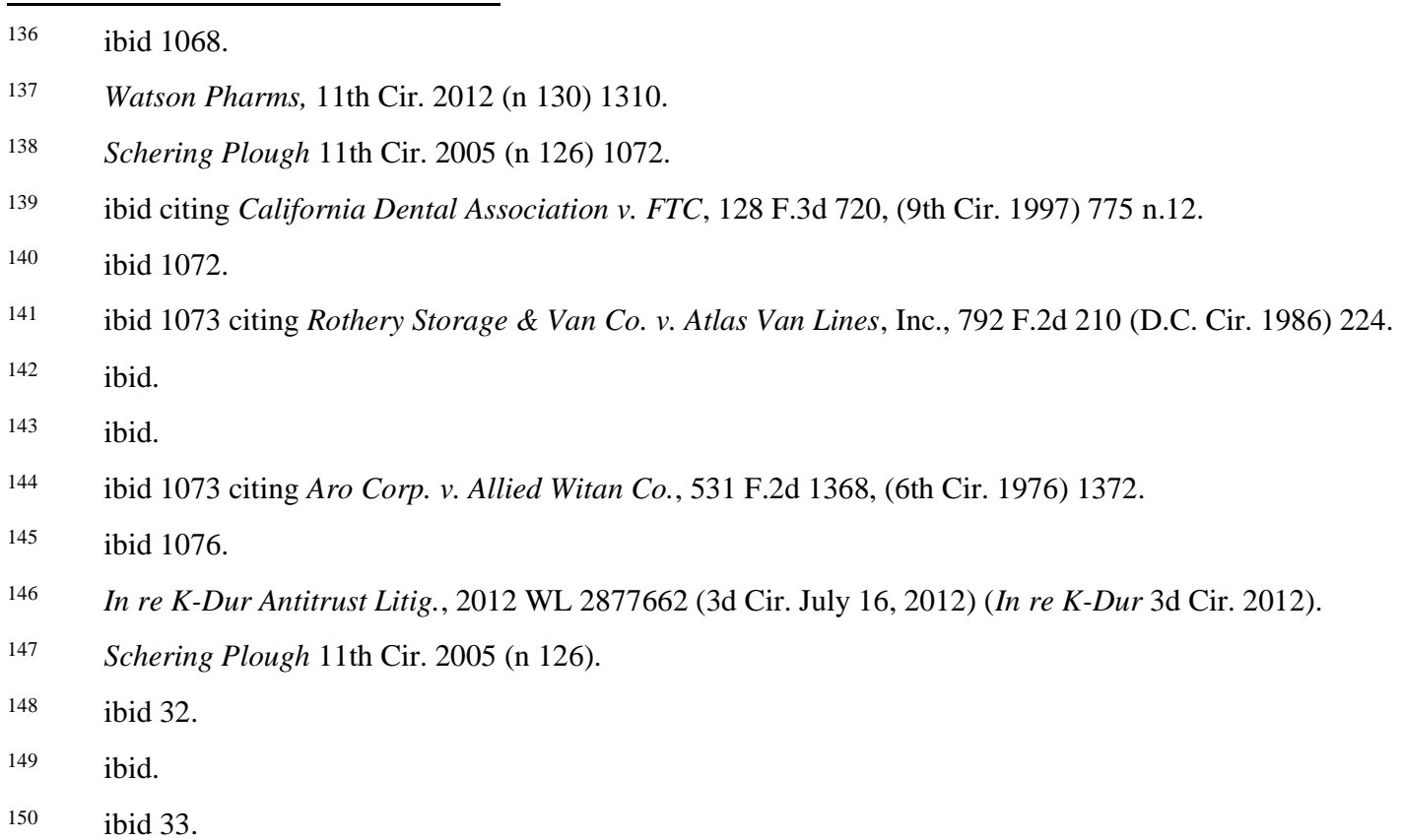


One may rebut this presumption by showing that the payment (1) was for a purpose other than delayed entry or (2) offers some pro-competitive benefit. ${ }^{151}$

\subsubsection{Brief Conclusions on the U.S. Courts' Tests}

Despite the courts' different approaches, namely the per se test, rule of reason and scope of the patent test, they ultimately arrived at the same conclusion: as long as the scope of the patent covers the agreement and this patent was not procured by fraud or the litigation is not baseless, the agreement is lawful and does not violate antitrust law.

One may well argue that this practice was almost settled until recently. However, the Third Circuit undermined the practice with its decision ${ }^{152}$ which refused to consider the reverse payment agreements from the patent/antirust point of view and instead concentrated on the existence of the reverse payment. As a result, there currently exist two Appellate Court decisions - by the Third and the Eleventh Circuits - which, through different approaches, arrived at opposite conclusions regarding the same agreements. ${ }^{153}$

Notably, the decision of the Eleventh Circuit is often cited for triggering the increased number of reverse payment agreements. ${ }^{154}$ The Third Circuit's decision regarding the same agreements may well lead to a prohibition of, or limitations imposed on, reverse payment agreements. In any case the Third Circuit's decision may mark the reason for the Supreme Court to decide this issue and finally define the coherent evaluative approach.

\subsection{General Rules Inferred From the U.S. Case Law}

As was noted above, disputes regarding reverse payment agreements are comparatively a new type of disputes in the U.S., and some circuits still need to consider them at a 'first impression'. Analysing the U.S. case law reveals a divergence in the evaluation techniques applied to these agreements, and legal society thus advocates for the harmonising the case law by implementing a coherent approach for treating and deciding on such disputes, ${ }^{155}$ as some fear that these divergences may lead to opposite decisions regarding the same kind of agreements. ${ }^{156}$ There are indications, however, that despite the above factors courts in general consistently segregate the specific types of reverse payment agreements. This practice derives from common rules from the previous antitrust and patent case law, and from new rules emerging from the recent case law on pay-for-delay agreements. ${ }^{157}$ Analysing the courts' decisions infers the following general rules, which the courts explicitly or implicitly accept and which relate to the disputes regarding reverse payment agreements.

\footnotetext{
151 ibid.

$152 \quad$ In re K-Dur 3d Cir. 2012 (n 146).

153 In re K-Dur 3d Cir. 2012 (n 146) and Schering Plough 11th Cir. 2005 (n 146).

154 Jon Leibowitz, Comm'r, FTC, 'Exclusion Payments to Settle Pharmaceutical Patent Cases: They're B-a-a-a-ck!, Address at the Second Annual In-House Counsel's Forum on Pharmaceutical Antitrust 8 (April 24, 2006) 3 <http://www.ftc.gov/speeches/leibowitz/060424PharmaSpeechACI.pdf.> accessed 7 August 2012; see also FTC Payfor-Delay Study (n 11) 1.

$155 \quad$ Yvon (n 43)1908, 1912.

156 This was already proved by the recent decision of the Third Circuit. See In re K-Dur 3d Cir. 2012 (n 146).

157 The exception to this generalisation is the Third Circuit's recent decision. See In re KDur 3d Cir. 2012 (n 146).
} 


\subsubsection{Presumption of Patent Validity}

Some argue that reverse payment settlements fall within the exclusionary scope of the patents in question, provided those patents are valid. ${ }^{158}$ Thus, in considering this type of disputes, the courts generally refer to the presumption of patent validity established in the law. ${ }^{159}$ Based on this presumption, courts consider the issue of the reverse payment agreements' compatibility with the competition rules without prior revision of patent validity.

However, some authors question this legal presumption. ${ }^{160}$ What if the patent is weak or obviously invalid? The proper challenge would result in the revocation or invalidity of the patent. ${ }^{161}$ Concluding the settlement in such a case could prevent such outcomes and thus unduly extend the period of protection enjoyed by the patent holder. ${ }^{162}$ As the Second Circuit acknowledged:

If courts do not discount the exclusionary power of the patent by the probability of the patent's being held invalid, then the patents most likely to be the subject of exclusion payments would be precisely those patents that have the most questionable validity. ${ }^{163}$

Some argue that, if any of the presumptions regarding the patent validity fall, the agreement undoubtedly marks an unlawful restraint of trade. ${ }^{164}$ Therefore, the question is whether the courts should consider patent validity as part of their analyses of these disputes. ${ }^{165}$ Answering this question, the Federal Circuit agreeing with the Second and Eleventh Circuits stated that, if there is no evidence that a patent was procured by fraud or that litigation is sham, there is no need to consider patent validity in this type of dispute. ${ }^{166}$

Although this presumption of patent validity is generally considered irrefutable, the Third Circuit questioned it in its recent decision. The Court stated that, rather than adopting such a presumption, it should be taken into account that 'a patent, in the last analysis, simply represents a legal conclusion reached by the Patent Office.' 167 The Court concluded that 'the public interest supports judicial testing and elimination of weak patents. ${ }^{168}$

The Court determined that, with respect to reverse payments agreements, such logic is persuasive: as they 'permit the sharing of monopoly rents between would-be competitors without any assurance that the underlying patent is valid'. ${ }^{169}$ The Court explained that the goal of Hatch-Waxman Act is 'to increase

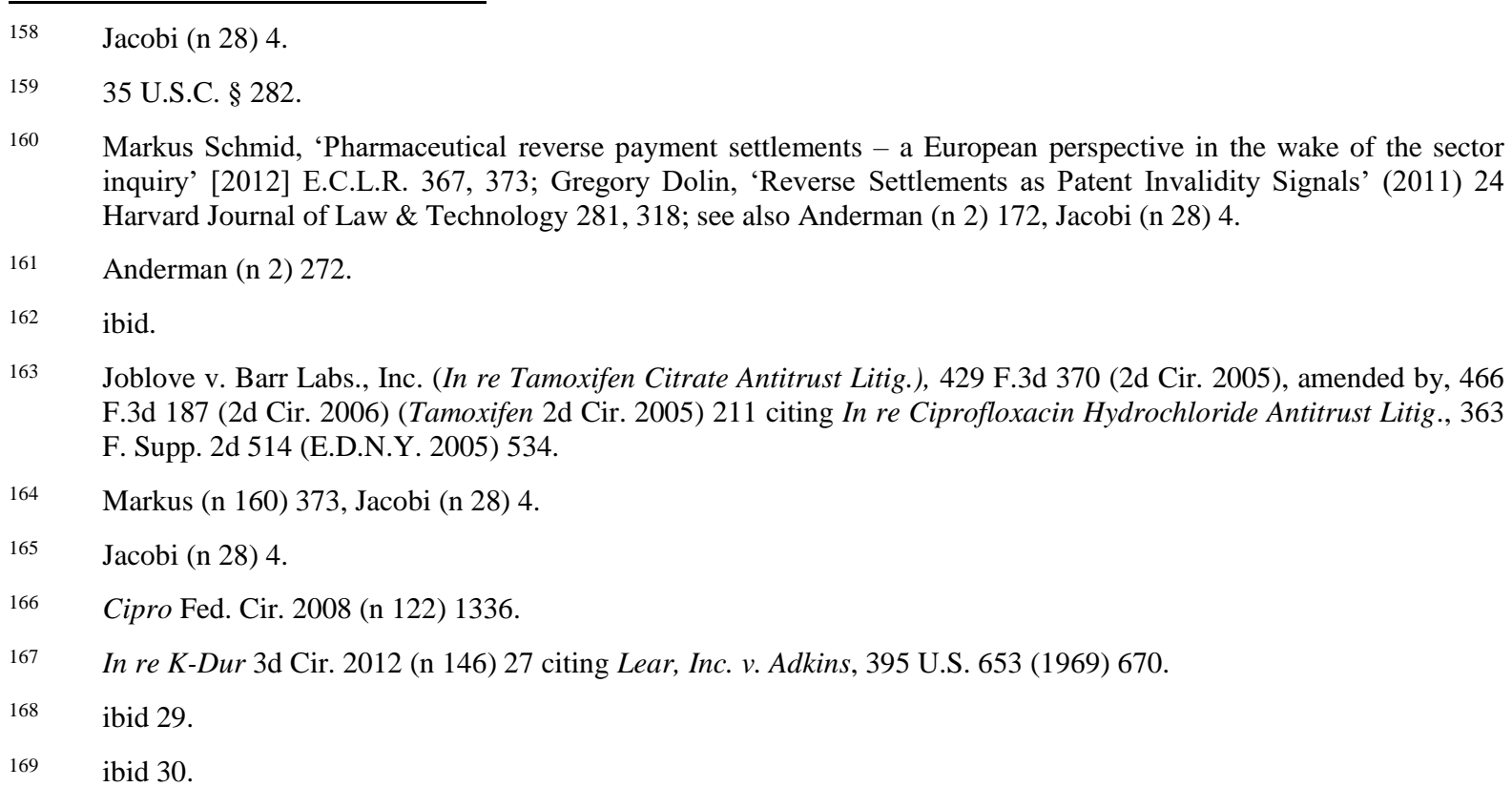


the availability of low cost drugs'. ${ }^{170}$ Thus, in aiming to achieve this goal, it allows for the generic companies to challenge the brandname companies' weak or narrow patents. ${ }^{171}$

\subsubsection{The Scope of the Patent}

Most of the courts have accepted that, as long as agreement falls within the scope of patent protection, it should be deemed lawful and consistent with the competition law. ${ }^{172}$ Analysing the reverse payment settlement agreement, the Second Circuit admitted that the agreement in question was doubtless anticompetitive, ${ }^{173}$ as it limited competition between a branded product and its generic version. ${ }^{174}$ However, since it did not exceed the scope of the patent, it was not an unlawful anticompetitive agreement. ${ }^{175}$ In this respect, it is important to define the scope of the patent, which is seen to include the claims covered by the patent, term of protection and geographical area. ${ }^{176}$ The patent confers the right to exclude others from profiting from the patented invention. ${ }^{177}$ Patents do not, however, extend the patentee's monopoly beyond its statutory right to exclude. ${ }^{178}$ The Second Circuit held that the settlement agreement did not exceed the scope of the patent where: (1) there was no restriction on marketing non-infringing products; (2) a generic version of the branded drug would necessarily infringe the branded firm's patent; (3) the agreement did not bar other generic manufacturers from challenging the patent. ${ }^{179}$

One example of exceeding the scope of the patent is when a generic company agrees to refrain from ever marketing a generic version of a patented drug. ${ }^{180}$ This means that settlement agreement will block generic competition after the patent expiration, and thus will exclude competition beyond the scope of exclusion granted by the patent. ${ }^{181}$ Another example is when a settlement agreement allows a generic company to retain its 180 -day exclusivity period even though it has no intention to market its generic drug. ${ }^{182}$ This stipulation means that the exclusivity period, which begins after the date of first commercial marketing, would never be triggered. ${ }^{183}$ As a result, 'the exclusivity period would have acted like a cork in a bottle, blocking other generic competition from pouring into the market. ${ }^{184}$ Thus the agreement creates anticompetitive effects beyond the scope of the patent. ${ }^{185}$

\footnotetext{
170 ibid 31 citing H.R. REP. NO. 98-857 (n 29).

$171 \quad$ ibid 31.

172 The Third Circuit in its recent decision has rejected this approach. ibid 32.

$173 \quad$ Tamoxifen 2d Cir. 2006 (n 119) 218.

174 ibid.

175 ibid.

176 3rd Monitoring Report (n 7).

177 Dawson Chem. Co. v. Rohm \& Haas Co., 448 U.S. 176, 215 (1980).

178 Mallinckrodt, Inc. v. Medipart, Inc. 976 F.2d 700, 708 (Fed. Cir. 1992).

Cipro 2d Cir. 2010 (n 114) 106 citing Tamoxifen 2d Cir. 2005 (n 119) 213-15.

180 Andrx Pharmaceuticals, Inc. v. Elan Corp., 421 F.3d 1227, 1235 (11th Cir. 2005) (Andrx Pharmaceuticals 11th Cir. 2005).

181 Watson Pharms, 11th Cir. 2012 (n 130) 1311 citing Andrx Pharmaceuticals 11th Cir. 2005, 1231 (internal citation omitted).

182 ibid citing Andrx Pharmaceuticals 11th Cir. 2005, 1231 (internal citation omitted).

183 ibid citing Andrx Pharmaceuticals 11th Cir. 2005, 1231 (internal citation omitted).

184 ibid.

185 ibid citing Andrx Pharmaceuticals 11th Cir. 2005, 1235 (internal citation omitted).
} 
However, the Third Circuit did not find the scope of the patent approach persuasive. ${ }^{186}$ Declining to follow it, the Court explained that it 'improperly restricts the application of antitrust law and is contrary to the policies underlying the Hatch-Waxman Act and a long line of Supreme Court precedent on patent litigation and competition. ${ }^{, 187}$

\subsubsection{Sham Litigation or Fraud in Obtaining a Patent}

The Federal Circuit stated that 'an antitrust violation could be found in the extreme situation where there was evidence of fraud on the PTO or sham litigation. ${ }^{188}$ Facing antitrust liability, a defendant may invoke the immunity under the Noerr-Pennington doctrine, which 'allows private citizens to exercise their First Amendment rights to petition the government without fear of antitrust liability.' 189 However, 'sham' conduct falls within exceptions to the doctrine. ${ }^{190}$ As the Second Circuit stated, 'the doctrine does not extend protection to the defendants 'where the alleged conspiracy is a mere sham to cover what is actually nothing more than an attempt to interfere directly with the business relationships of a competitor'. ${ }^{191}$

The situations in which the sham exception applies are defined as follows: first, where the lawsuit is objectively baseless and the defendant's motive in bringing it was unlawful; second, where the conduct involves a series of lawsuits brought pursuant to a policy of starting legal proceedings without regard to the merits and for an unlawful purpose; third, if the allegedly unlawful conduct consists of making intentional misrepresentations to the court, litigation can be deemed a sham if a party's knowing fraud upon, or its intentional misrepresentations to, the court deprives the litigation of its legitimacy. ${ }^{192}$ The third situation may be directed to not only a court but also the federal Patent and Trademark Office. ${ }^{193}$ The patent obtained by fraud grants unlawful monopoly to the patent holder and thereby violates antitrust law.

\subsubsection{The Agreement Must Settle the Dispute Finally}

The settlement must fully resolve litigation between the generic company and the originator company to enable the other generic manufacturers to enter the market. Interim settlements which aim to withdraw generic entry whilst the litigation is pending are viewed as unlawful. ${ }^{194}$ The Second Circuit stated that 'rather than resolve the litigation, the settlements in those cases prolonged it by providing incentives to the defendant generic manufacturers not to pursue the litigation avidly. ${ }^{195}$ The alleged purpose of this kind of agreement is to create a bottleneck: delaying the triggering of the 180-day

\footnotetext{
$186 \quad$ In re K-Dur 3d Cir. 2012 (n 146) 22.

$187 \quad$ ibid 27.

$188 \quad$ Cipro Fed. Cir. 2008 (n 117) 1335 citing Valley Drug 11th Cir. 2003 (n 132) 1309.

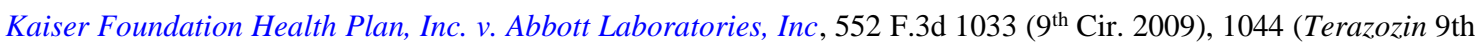
Cir. 2009) citing Eastern R.R. Presidents Conference v. Noerr Motor Freight, Inc., 365 U.S. 127 (1961) and United Mine Workers of Am. v. Pennington, 381 U.S. 657 (1965).

$190 \quad$ ibid 1045.

191 Tamoxifen 2d Cir. 2006 (n 119) 217 citing Cal. Motor Transp. Co. v. Trucking Unlimited, 404 U.S. 508, 511 , 92 S. Ct. 609, 30 L. Ed. 2d 642 (1972) (quoting Noerr, 365 U.S. at 144).

192 Terazozin 9th Cir. 2009 (n 189) 1045 citing City of Columbia v. Omni Outdoor Adver., Inc., 499 U.S. 365,380 (1991).

193 Terazozin 9th Cir. 2009 (n 189) 1045 citing Sosa v. DIRECTV, Inc., 437 F.3d 923, 938 (9th Cir. 2006).

194 Andrx Pharmaceuticals, Inc. v. Biovail Corp. International, 256 F.3d 799 (D.C. Cir. 2001), cert. denied, 535 U.S. 931 (2002) (Andrx D.C. Cir. 2001). 
exclusivity period in turn delays the entry of both the first filer and any other potential generic company. ${ }^{196}$

\subsubsection{Likelihood to Prevail in the Dispute}

Although courts have rejected the 'likelihood to prevail in the dispute' approach, it is one worth noting as the FTC firmly stands by this position. In one case involving the invalidation of the patent after the settlement agreement, the Eleventh Circuit held that in case the decision about the patent invalidity was held after the settlement agreement this decision should not be taken into account. ${ }^{197}$ All that matters is the patent's 'potential exclusionary power as it appeared at the time of settlement.' 198

The FTC has developed a 'not likely to prevail' test, arguing that 'a patent has no exclusionary potential if its holder was not likely to win the underlying infringement suit.' ${ }^{199}$ It also argues that 'if the patent has no exclusionary potential then any reverse payment settlement that excludes any competition from the market necessarily exceeds the potential exclusionary scope of the patent and must be seen as the patent holder's illegal 'buying off' of a serious threat to competition. ${ }^{200}$ The FTC advocates adopting a rule according to which 'an exclusion payment is unlawful if, viewing the situation objectively as of the time of the settlement, it is more likely than not that the patent would not have blocked generic entry earlier than the agreed-upon entry date. ${ }^{201}$

The Eleventh Circuit rejected this proposed test firmly, holding that:

Rational parties settle to cap the cost of litigation and to avoid the chance of losing. Those motives exist not only for the side that is likely to lose but also for the side that is likely, but only likely, to win. A party likely to win might not want to play the odds for the same reason that one likely to survive a game of Russian roulette might not want to take a turn. With four chambers of a seven-chamber revolver unloaded, a party pulling the trigger is likely (57\% to $43 \%$ ) to survive, but the undertaking is still one that can lead to undertaking. ${ }^{202}$

\subsection{Examples of Reverse Payment Agreements as Decided by U.S. Courts}

The following are examples of terms and conditions of the reverse payment agreements which violate antitrust law, as decided by U.S. courts:

\subsubsection{Examples of Unlawful Reverse Payment Agreements}

\footnotetext{
196 In re K-Dur 3d Cir. 2012 (n 146) 20 citing Andrx D.C. Cir. 2001, 804.

$197 \quad$ Watson Pharms, 11th Cir. 2012 (n 130) 1308.

$198 \quad$ ibid citing Valley Drug 11th Cir. 2003 (n 132) 1311.

199 ibid, 1312.

200 ibid.

201 ibid.

202 ibid 1313.
} 


\section{(a) Agreement Recognised As Per Se Illegal}

Agreement contained payments from the originator company to the generic company beginning on the date of FDA approval obtained by the generic company and ending on the date when the generic company started selling its generic version of the patented drug or when the court considering the patent infringement dispute recognised the infringement. In return, the generic company promised not to market its generic version of a patented drug even after the FDA approval. The agreement included generics which did not infringe the patent and promise by the generic company not to relinquish the 180-day period of market exclusivity. ${ }^{203}$

The Sixth Circuit held that such restrictions on market entry coupled with payments, non-infringing product and abuse of the 180-day market exclusivity precluding subsequent generic companies from entering the market are per se unlawful and violate antitrust law. Therefore, the court recognised this agreement 'at its core, a horizontal agreement to eliminate competition in the market for a [patented drug] (...) a classic example of a per se illegal restraint of trade. ${ }^{, 204}$

\section{(b) Agreement Recognised As Illegal under the 'Scope of the Patent' Test}

Agreement contained recognition of the patent infringement by the generic company and promise to refrain from ever entering the market with its generic version of the drug in exchange for a license from brand-name company to manufacture a generic controlled version of the drug. ${ }^{205}$

The Eleventh Circuit held that the promise to refrain from ever marketing a generic version of patented drug would block generic competition after the patent expired, and thus excluded competition beyond the scope of exclusion granted by the relevant patent. ${ }^{206}$ The agreement also allowed the generic company to retain its 180-day exclusivity period even though that company had no intention to market its generic drug. ${ }^{207}$ This agreement would have acted 'like a cork in a bottle, blocking other generic competition'. Therefore, the Court determined that the settlement yielded anticompetitive effects beyond the scope of he patent and was unlawful. ${ }^{208}$

\section{(c) Common Features of Agreements Which Were Held Unlawful}

When evaluating the provisions of the above reverse payment agreements, the courts used different tests for their evaluations, yet the outcome was the same: these agreements were held unlawful. Comparing the provisions of these two agreements indicates that they have a common feature: their provisions, such as non-infringing product, refraining from ever marketing generic version and abuse of market exclusivity, go beyond the scope of the patent protection. Therefore, despite applying different tests, the courts reached the same conclusion that these agreements violate antitrust law.

\footnotetext{
203 Cardizem 6th Cir. 2003 (n 108).

$204 \quad$ ibid 908.

205 Andrx Pharmaceuticals 11th Cir. 2005 (n 180).

206 Watson Pharms, 11th Cir. 2012 (n 130) 1311.

207 ibid citing Andrx Pharmaceuticals 11th Cir. 2005 (n 180) 1231.

208 ibid 1311.
} 


\subsubsection{Examples of Lawful Reverse Payment Agreements}

The following reverse payment agreements were found lawful:

\section{(a) Agreement Held Lawful Under the 'Rule of Reason' Approach}

According to the agreement, the originator company agreed to pay a lump sum immediately and make quarterly payments for the duration of the patent, except for the last six months before the patent's expiration. The originator also agreed to provide the generic manufacturers a guaranteed licence to sell brand-name drug at a reduced rate for the six months before the patent's expiration. In exchange, generic company recognised the patent validity and agreed not to market its generic version of a drug before the patent's expiration. ${ }^{209}$ The Second Circuit found that the agreement is lawful as it falls within the scope of the patent. ${ }^{210}$

\section{(b) Agreement Held As Lawful under the 'Scope of the Patent' Test}

Generic companies agreed not to market generic versions of a drug until five years before patent expiration unless another manufacturer launched its generic drug beforehand. They also agreed to promote branded drug to doctors and to serve as a backup manufacturer for branded drug. Originator company, in return, agreed to make yearly payments and additional annual payments for the backup manufacturing assistance. ${ }^{211}$ The court agreed with the district court that the agreement did not exceed the scope of the patent. ${ }^{212}$

\section{(c) Common Features of the Agreements That Were Held Lawful}

Notably, these agreements contain restrictions on both generic market entry and value transfer from the originator company to the generic company. They also were evaluated under different approaches. Nevertheless, courts declared them lawful because they fell within the scope of the patent. As stated by the Federal Circuit: 'wherein all anticompetitive effects of the settlement agreement are within the exclusionary power of the patent, the outcome is the same whether the court begins its analysis under antitrust law by applying a rule of reason approach to evaluate the anti-competitive effects, or under patent law by analysing the right to exclude afforded by the patent. ${ }^{213}$

\subsubsection{Conflicting Decisions of the Eleventh and the Third Circuits}

Currently, there exist two conflicting decisions regarding the same agreement. The reverse payment agreements decided by both Circuits restricted the generic entry date to one earlier than patent expiration, the licence from the generic company to the originator company and payments from the originator company to the generic company which included legal fees and royalty for the licence. ${ }^{214}$

On 8 March 2005 the Eleventh Circuit considering the dispute held this agreement lawful as it fell within the scope of patent protection. ${ }^{215}$ It took into account that the settlement excluded competition

\footnotetext{
$209 \quad$ Cipro 2d Cir. 2010 (n 114).

210 ibid, 103, 110.

211 Watson Pharms, 11th Cir. 2012 (n 130).

212 ibid, 1306, 1315.

$213 \quad$ Cipro Fed. Cir. 2008 (n 117) 1336.

$214 \quad$ Schering Plough 11th Cir. 2005 (n 126), In re K-Dur 3d Cir. 2012 (n 146)

215 ibid, 1076.
} 
for a shorter period before the patent expiration. ${ }^{216}$ It also held that payments from originator to generic company were a 'fair price' for the product under the licence granted by the generic company to originator, and therefore the aim of these payments was not to delay the market entry. ${ }^{217}$ Therefore, the Court rejected 'a rule of law that would automatically invalidate any agreement where a patent-holding pharmaceutical manufacturer settles an infringements case by negotiating the generic's entry date, and, in an ancillary transaction, pays for other products licences by the generic'. ${ }^{218}$

On 16 July 2012, the Third Circuit considering the same agreements disagreed with the Eleventh Circuit and rejected the scope of the patent test. Instead, the court applied a quick look rule of reason analysis. It declared that any payment from patent holder to a generic company which promises to refrain from entering the market should be treated as prima facie evidence of unreasonable restraint of trade, unless it is proved that the payment did not seek to delay the generic market entry or offers a procompetitive effect. $^{219}$

As stated above, these two decisions sharply divided the circuits that prior to the latter decision despite the diverse approaches applied to the reverse payment agreements had ultimately arrived at a similar conclusion. Considering the importance of the issue, which concerns both public and private interests and which may distort the fragile balance between intellectual property protection and competition rules, this disagreement between circuits must be resolved. It is up to the Supreme Court or the legislative authorities to upend this discrepancy in the case law and to settle the coherent practice within the U.S. courts.

\section{EU Developments: Approaches and General Rules in Disputes Regarding Patent Settlement Agreements}

Although the EU lacks relevant case law regarding reverse payment agreements, it may prove helpful to explore the evolving pattern in the U.S. jurisprudence and modify it for the EU, and to infer approaches and general principles from the previous EU case law which might apply to reverse payment agreements.

\subsection{Incorporating the U.S. Approaches and Tests for Reverse Payment Agreements into the European Legal Framework}

It is generally viewed that the EU competition authorities' position would likely follow the U.S. courts' approaches to assessing reverse payment agreements based on the exclusionary scope of a patent. ${ }^{220} \mathrm{In}$ this respect, and considering the lack of relevant case law in the EU, it is interesting to analyse whether European courts may use the US courts' current approaches and tests in disputes regarding reverse payment agreements. To understand whether the U.S. judicial approaches would suit the European competition environment, one must grasp the peculiarities of the European competition legal framework compared to that of the U.S. At the very basic level, the difference between these regimes is that the EU promotes a single market under the main principle of free movement of goods among its Member

\footnotetext{
216 ibid, 1068.

217 ibid, 1071.

218 ibid, 1076.

219 In re K-Dur 3d Cir. 2012 (n 146), 33. See analysis to n 146-151.

220 William H. Rooney and Elai Katz, 'Review of Reverse Payment Agreements: The Agencies, the Courts, Congress, and the European Commission’ (2009) 5 Competition Policy International 120, 136.
} 
States, which does not occur in U.S. competition law.

Section 1 of the Sherman Act and its sister provision (albeit not identical) article 101 (1) TFEU aim to tackle practices which restrict competition in these two regimes. ${ }^{221}$ However, as discussed above, article 101 goes further and offers in its paragraph 3 exceptions to the prohibitions set forth in paragraph 1. Therefore, the EU analysis of possible anticompetitive effect found within the scope of paragraph 1 will ultimately evaluate whether the agreement may be exempt under paragraph 3 . These particularities cause certain difficulties in applying the U.S. tests and approaches to the EU realia.

Moreover, as there are no provisions in the EU equivalent to the Hatch-Waxman Act which provides an exclusivity period to the first to file generic company, a reverse payment in the EU would only delay entry of the generic company which is a party to the agreement and would not delay generic entry in the market to any other generic company. ${ }^{222}$ Therefore, it may be argued, that the potential effects of a reverse payment are likely to be less restrictive of competition in the EU than in the U.S. I

$\mathrm{n}$ further discussing possible applications of the U.S. approaches and tests analysed in section 4 of this article, the following will suggest relevant modifications subject to the EU law peculiarities in general, and to the specific nature of reverse payments agreements in particular.

\subsubsection{Modified Per Se Test}

As shown above, ${ }^{223}$ the U.S. case law addresses certain types of trade practices which are considered plainly anticompetitive. ${ }^{224}$ These practices include agreements which fix purchase or selling prices, share markets or limit production. ${ }^{225}$ It was recognised that, where the agreement is plainly anticompetitive, the per se approach will be used. It was explained that the chances that these practices will not prove anti-competitive are so limited that, for reasons of judicial economy and certainty of law, they should be considered prohibited ex ante, without having to evaluate their actual competitive value. $^{226}$

The General Court ${ }^{227}$ acknowledged such an approach in the European Night Services \& Co. v. Commission, which stated that:

in assessing an agreement under Article [101] (1) of the Treaty, account should be taken of the actual conditions in which it functions (...) unless it is an agreement containing obvious restrictions of competition such as price-fixing, market-sharing or the control of outlets. 228

However, article 101 TFEU excludes the possibility of such ex ante analysis. ${ }^{229}$ Paragraph 3 states that 'any' practice restricting competition and prohibited under paragraph 1 may be exempt from the

\footnotetext{
221 Pietro Manzini, 'The European rule of reason-crossing the sea of doubt' (2002) 23(8) European Competition Law Review 392, 384.

222 Gavin Robert and Fabio Falconi, 'Patent litigation settlement agreements in the pharmaceutical industry: marrying the innovation bride and competition groom' (2006) 27(9) European Competition Law Review 524, 532.

$223 \quad$ See section 4.

224 See text to $\mathrm{n} 108-113$

225 Cardizem 6th Cir. 2003 (n108) 907 citing National College Athletic Ass'n v. Board of Regents, 468 U.S. 85, 100 (1984), Manzini (n 221) 394.

226 Cardizem 6th Cir. 2003 (n 108) 907, Manzini (n 221) 392.

227 The then Court of First Instance.

228 Cases T-374/94, T-375/94, T-384/94 and T-388/94, ENS \& Co v. Commission, [1998] E.C.R. II-3141, para 136.

$229 \quad$ Manzini (n 221) 398.
} 
prohibition if it satisfies all conditions set forth in paragraph 3. ${ }^{230}$ In the Matra Hachette v. Commission the General Court stated that:

in principle, no anti-competitive practice can exist which, whatever the extent of its effects on a given market, cannot be exempted, provided that all the conditions laid down in Article [101](3) of the Treaty are satisfied. ${ }^{231}$

Thus, contrary to the U.S. legal doctrine, the EU legal framework requests an evaluation of the pro and anti-competitive effects of practices, not immediately under article 101 (1) TFEU, but further under article 101 (3) TFEU. ${ }^{232}$

\subsubsection{Modified 'Rule of Reason' Test}

The rule of reason doctrine has evolved in the U.S. jurisprudence and evaluates the pro- and anticompetitive aspects of a given agreement. ${ }^{233}$ As the Supreme Court has stated, there are certain types of 'agreements whose anti-competitive effect can only be evaluated by analysing the facts peculiar to the business, the history of the restraint and the reason why it was imposed' ${ }^{234}$ Before 2001, there was no defined position of whether the rule of reason exists in the EU competition law. ${ }^{235}$ Some suggestions for implementing this test date back to the late-1960s. ${ }^{236}$ However, despite this doctrinal support, the CJEU was not convinced of the possibility to apply the rule of reason under article 101 (1) TFEU. ${ }^{237}$

The Métropole Télévision decision resolved all doubts regarding the rule of reason test. ${ }^{238}$ In this case, the applicants argued that the Commission should have applied the then equivalent of article 101 (1) TFEU in light of a rule of reason, under which an anti-competitive practice falls outside the scope of its prohibition if it has more positive than negative effect on competition in a given market. ${ }^{239}$ However, the General Court held that such an interpretation of article 101 (1) TFEU was difficult to reconcile with the rules prescribed by that provision. ${ }^{240}$ Firmly rejecting this suggestion, the Court held that article [101 (3) TFEU] expressly allows for the possibility of exempting agreements which restrict competition if they fulfil the conditions prescribed by this paragraph. ${ }^{241}$ The Court emphasised that, only within this provision, one could apply the pro- and anti-competitive analysis of a restriction. It added that:

Article [101 (3) TFEU] would lose much of its effectiveness if such an examination had to be carried out already under article [101 (1) TFEU]. ${ }^{242}$

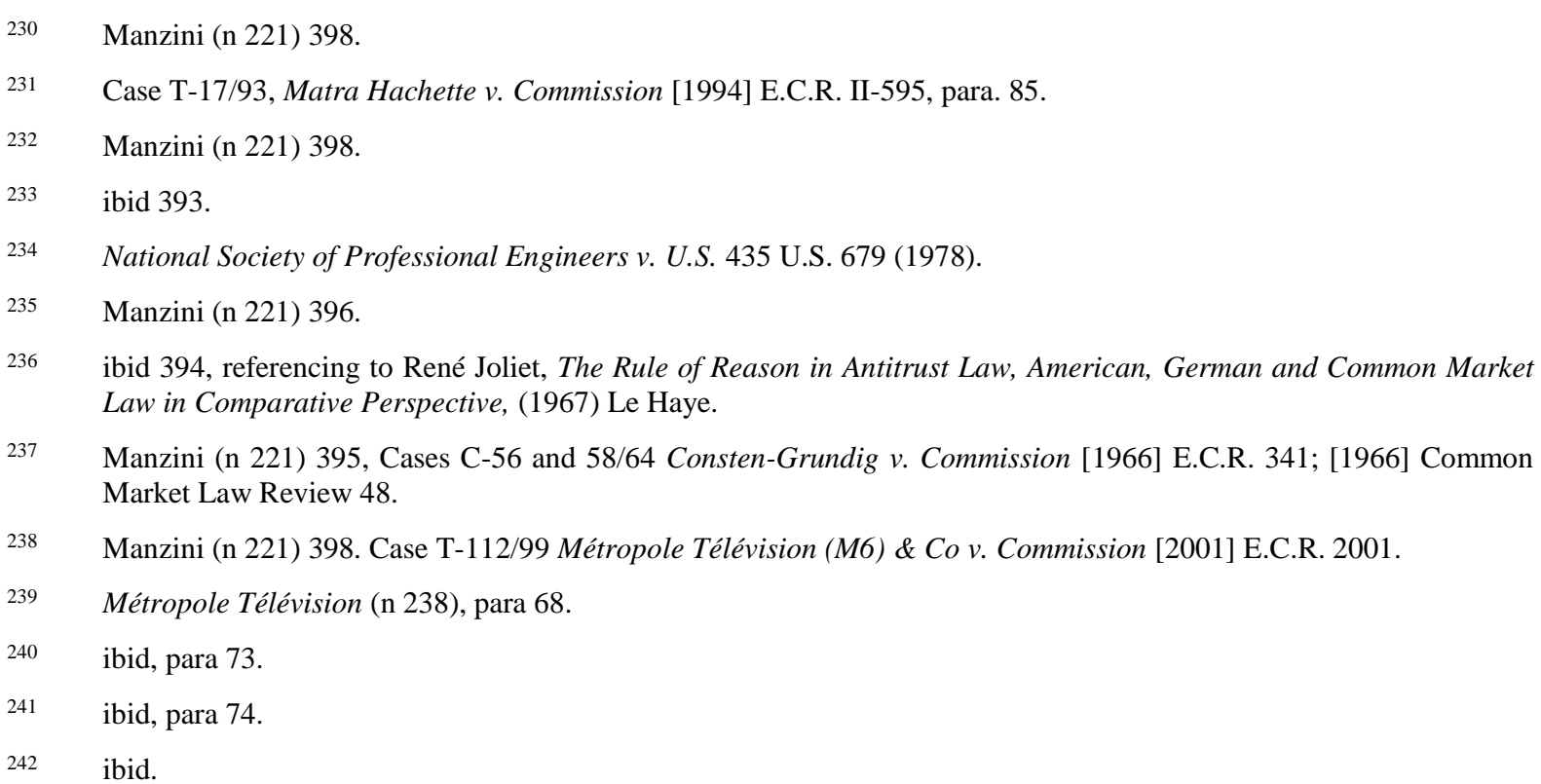


Thus, this decision implies that one cannot incorporate the rule of reason in its initial form from the U.S. case law into article 101 (1) TFEU. Rather, the balance of pro- and anti-competitive effects must be drawn on the basis of Article 101(1) in conjunction with article 101(3) TFEU. ${ }^{243}$

\subsubsection{Ancillary Restraints Doctrine in European Case Law}

Ancillary restraints are restraints which are needed to conclude a lawful contract, and their importance is subordinate to the latter. ${ }^{244}$ The CJEU stipulated that the ancillary restraints to competition which are necessary to conduct a lawful practice do not fall within the scope of Article 101(1) TFEU. ${ }^{245}$ Thus, in the Remia v. Commission case, the Court recognised that such restraints were necessary for the noncompetition agreements included in sale of business contracts which 'have the merit of ensuring that the transfer has the effect intended', ${ }^{246}$ as long as their duration and scope are strictly limited to this purpose. ${ }^{247}$

In Métropole Télévision, the General Court had discussed the ancillary restraints doctrine when considering the applicant's claim that the exclusivity clause and the clause relating to the special-interest channels were ancillary to their joint venture. The applicant argued that, since the Commission had found that the joint venture did not infringe article 101(1) TFEU, the ancillary clauses should also have been cleared. $^{248}$

In its findings, the General Court stated that 'the concept of an "ancillary restriction" covers any restriction which is directly related and necessary to the implementation of a main operation. ${ }^{249}$ The Court held that "a restriction "directly related" to implementation of a main operation must be understood to be any restriction which is subordinate to the implementation of that operation and which has an evident link with it' ${ }^{250}$ The Court defined two conditions for satisfying the necessity test: it must establish, first, whether the restriction is objectively necessary to implement the main operation and, second, whether the restriction is proportional to it. ${ }^{251}$

For the finding of the objective necessity, the court determined that '[i]f, without the restriction, the main operation is difficult or even impossible to implement, the restriction may be regarded as objectively necessary for its implementation. ${ }^{252}$ The Court referred to the Commission's findings that a number of restrictions were objectively needed to implement certain operations if, failing such restrictions, the operation in question 'could not be implemented or could only be implemented under more uncertain conditions, at substantially higher cost, over an appreciably longer period or with considerably less probability of success' ${ }^{253}$ When the restriction was found objectively necessary to implement a main operation, 'it is still necessary to verify whether its duration and its material and

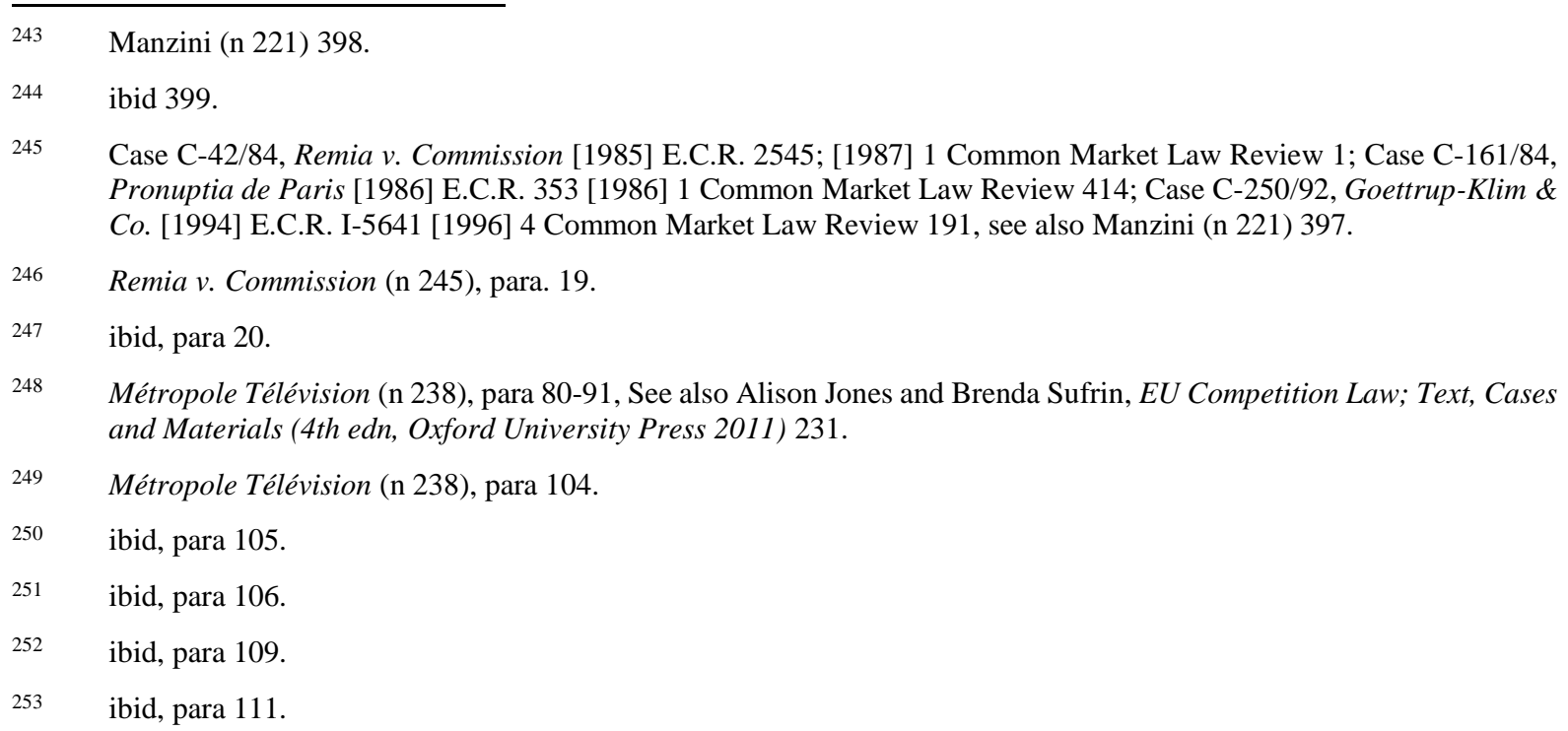


geographic scope do not exceed what is necessary to implement that operation. ${ }^{254}$ The Court explained that '[i]f the duration or the scope of the restriction exceed what is necessary in order to implement the operation, it must be assessed separately under article [101(3) TFEU]. ${ }^{255}$

If the direct relation and the necessity conditions to achieve a main operation are established, one may examine the compatibility of that restriction with the competition rules together with that of the main operation. ${ }^{256}$ Therefore, if the main operation is found not to infringe article 101(1) TFEU, the same result must be found for the restrictions directly related to and necessary for that operation. ${ }^{257}$ Alternately, if the main operation found to infringe article 101 (1) TFEU may be exempted under article 101(3) TFEU as it satisfies its conditions, the exemption also extends to the ancillary restrictions. ${ }^{258}$

\subsubsection{Possible Way to Assess the Reverse Payment Agreements under EU Competition Law}

Applying the aforementioned approaches of the EU case law, one may suggest the following assessment of reverse payments agreements. Article 101(1) TFEU defines that an agreement falls within its prohibition when it has as its object or effect the prevention, restriction or distortion of competition. One may argue that the main purpose of the reverse payment agreements is to settle a patent dispute, thus ending the high-cost litigation which would last a considerable period. Settling the dispute therefore marks a main operation. The European Commission in its Guidelines has acknowledged in terms of the 'non-challenge clauses' that 'the very purpose of the agreement is to settle existing disputes and/or to avoid future disputes' ${ }^{259}$ Therefore, it is possible to conclude that such an agreement falls outside the scope of article 101 (1) TFEU.

The provisions of the settlement agreement which limit generic competition (such as licence agreement) and contain the value transfer from the originator company to the generic company may be deemed ancillary restraints to the main operation. To conclude that limitation on generic competition and reverse payment are ancillary restraints, parties must prove that such restraints are directly related and necessary to implementing the main agreement, namely settling the dispute.

The restraints relate directly to the main transaction if they are subordinate to the implementation of that transaction. ${ }^{260}$ As defined above, the settlement of the patent dispute is the main transaction. Thus, all provisions in the settlement which aim to resolve the dispute among the parties may be deemed subordinate, and thereby directly related, to implementing the transaction. Such settlement may include restrictions on the generic competition and certain value transfer from one party to another.

The necessity test is satisfied if it establishes the following two conditions: (a) it is objectively necessary for the implementing the main operation; (b) it is proportional to the main operation. ${ }^{261}$

Regarding the objective necessity, one may argue that, failing such restrictions, the parties would not agree to settle the dispute. For settlements to succeed, the generic company must acknowledge patent

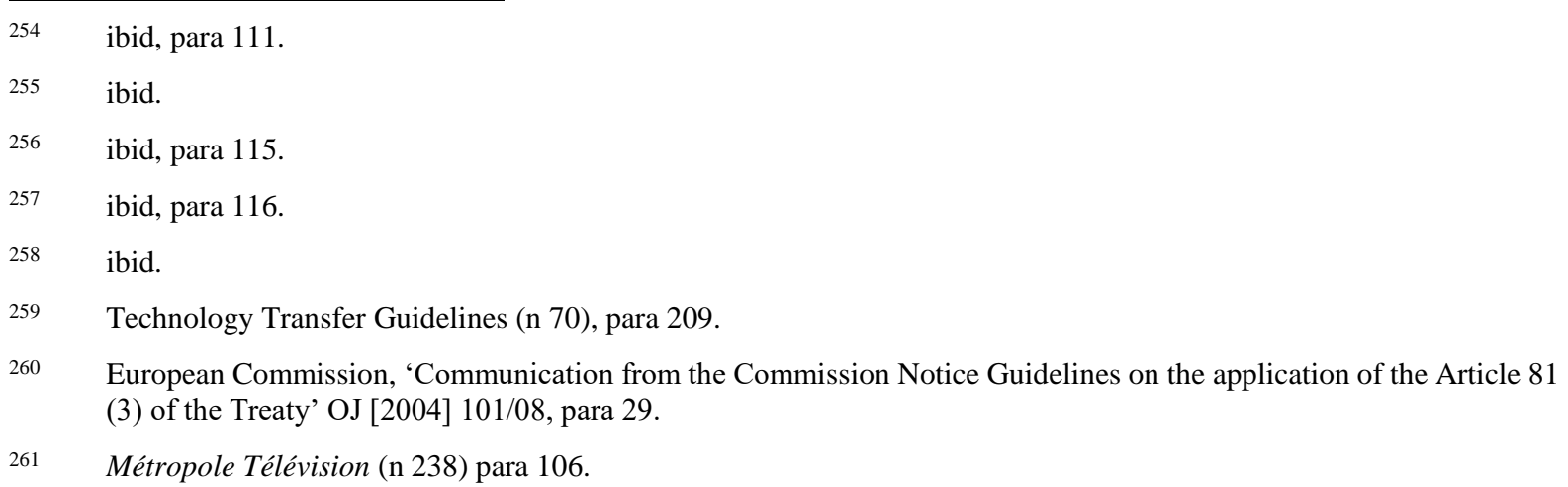


validity and promise not to infringe it in the future, that is not to enter the market whilst it is pending. Likewise, signing the licencing agreement could prove objectively necessary, as continuing litigation would lead to uncertain outcome 'at substantially higher cost, over an appreciably longer period or with considerably less probability of success. ${ }^{262}$ Regarding proportionality, here one may incorporate the theory of the scope of the patent. If such limitations fall within the scope of the patent (i.e. concern the product covered by the patent, within its term of protection and geographical area), the restrictions may be considered proportionate.

Thus, when such limitations on generic competition and reverse payment are found to be ancillary restraints, they must be further evaluated together with the main agreement. Therefore, as the settlement agreements fall outside Article 101 (1) TFEU so do the said ancillary restraints.

\subsection{General Rules Inferred from the EU Case Law}

Deciding on the patent settlement agreements, specifically in the form of licence agreements, the CJEU adhered to the following principles.

\subsubsection{The Scope of Intellectual Property Rights}

In its 3rd Report on the Monitoring of Patent Settlements, the Commission defined as potentially troublesome patent settlement agreements those with restrictions beyond the exclusionary zone of the patent, as they would not appear directly related to the intellectual property rights granted by the patents in question. ${ }^{263}$ According to the Commission, this position means that they would reach beyond its geographic scope, its period of protection or its exclusionary scope. ${ }^{264}$

The CJEU jurisprudence may support such a position. In one of its decisions relating to the licence agreement, the CJEU stated that the clauses contained in the licencing agreements, in so far as they relate to parts of the invention not covered by the patent, may find no justification on grounds of protecting an industrial property right. ${ }^{265}$ Deciding further on the compatibility of the above clause, the Court concluded that it cannot accept that the obligation of the licencee only to sell the patented product in conjunction with a product outside the scope of the patent is indispensable to exploiting the patent. ${ }^{266}$

The Court took the same position regarding the provisions which try to gain the protection granted by the patent in a country which lacks patent protection. ${ }^{267}$ The Court stated that it 'limited freedom of competition by means of a clause which had nothing to do with the patent. ${ }^{268}$ Moreover, in one of its decisions, the CJEU declared that the other party's abandoning of its right to advertise its product in the settlement agreement 'does not bear even the semblance of a connection with the question of the use of the [right concerned]' ${ }^{269}$

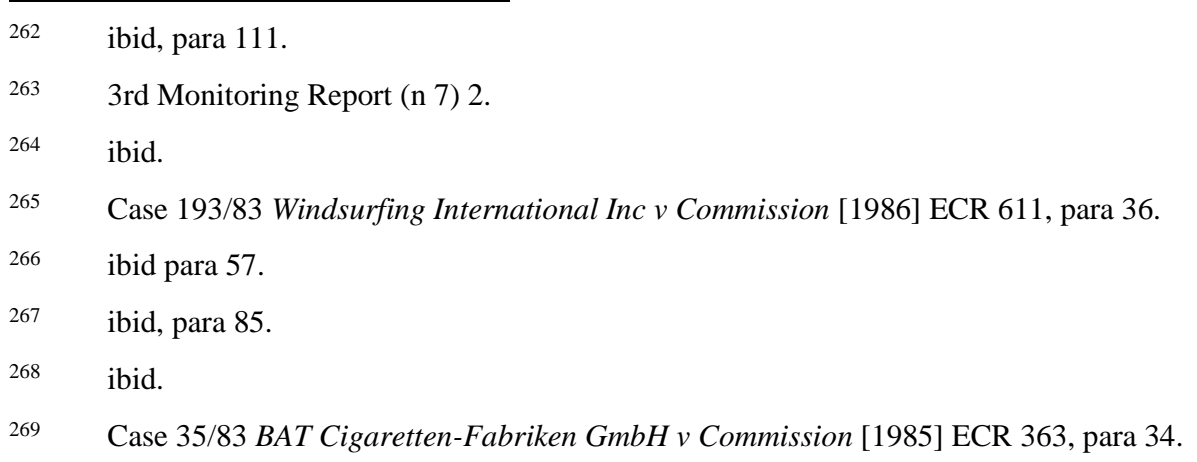


Applying this case law to the reverse payment agreements, one may conclude that, in cases where the agreements contain provisions which include products not covered by the patent, extend to the territory beyond that defined in the patent or contain obligations of the party which have no connection to the patent, such agreement will go beyond the scope of the patent and thus will likely trigger competition concerns.

\subsection{2. 'No-Challenge' Clause}

In its Technology Transfer Guidelines, the European Commission acknowledges the 'no-challenge' clause in the settlement agreement. It states that:

It is inherent in such agreements that the parties agree not to challenge ex post the intellectual property rights covered by the agreement. Indeed, the very purpose of the agreement is to settle existing disputes and/or to avoid future disputes. ${ }^{270}$

Thus, the Guidelines generally consider non-challenge clauses to fall outside Article 101 (1) TFEU. ${ }^{271}$ However, this position of the European Commission does not align with the previous CJEU case law. ${ }^{272}$ The Court considers such clauses to fall outside 'the specific subject matter of the patent, which cannot be interpreted as also affording protection against actions brought in order to challenge the patent's validity'. ${ }^{273}$ The Court emphasised: 'it is in the public interest to eliminate any obstacle to economic activity which may arise where a patent was granted in error'. ${ }^{274}$ Thus, such provisions were held as 'an unlawful restriction on competition'.275

\subsection{3. 'Sham' Conduct}

As stated above, licence agreements which settle a dispute are generally accepted. ${ }^{276}$ However, this tendency may be true only in case of a genuine dispute about a valid right. ${ }^{277}$ When 'the dispute is sham, or if the right is itself invalid any "settlement" agreement involving restrictions of competition" ${ }^{278}$ will fall under Article 101 (1) TFEU. 279

In BAT Cigaretten-Fabriken GmbH v Commission, the CJEU considered the compatibility of a settlement agreement known as 'delimitation agreement' with the competition law. ${ }^{280}$ The agreement concerned the settlement of a trademark dispute related to one party's application for trademark registration and the other party's opposition, though the trademark proved to be dormant.

The Court stated that the opposition by 'the proprietor of an unused, dormant, trade mark which is liable to be removed from the register upon application by any interested party (...) as part of its efforts to

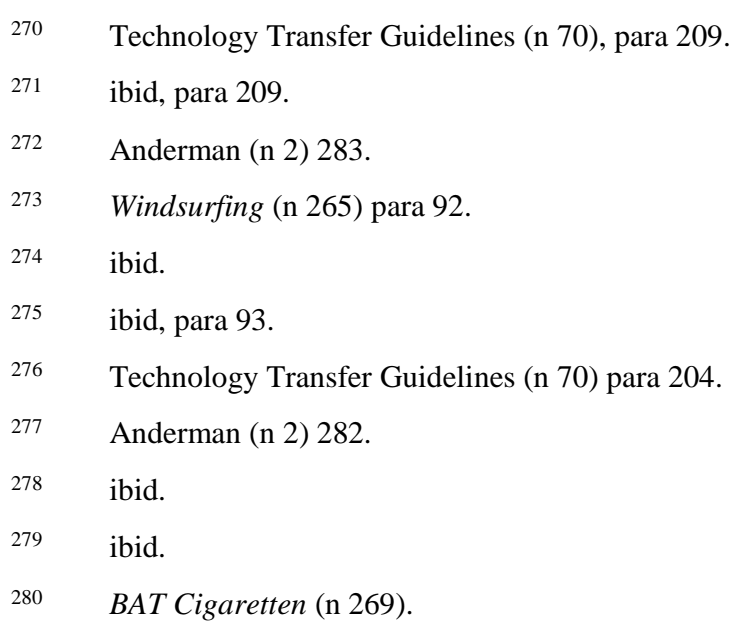


control the distribution of the [other party's] products, constitute an abuse of the rights conferred upon it by its trade mark ownership. ${ }^{281}$ Thus, the Court found that this agreement fell within the prohibition of Article 101 (1) TFEU.

Therefore, in applying the CJEU's conclusions to reverse payment agreements, one may contend that settling a patent dispute is lawful unless the originator's enforcement of a patent is a sham due to patent invalidity. These actions will likely qualify as abuse of the rights conferred upon by the patent and will fall within the prohibition laid down by Article 101 (1) TFEU.

\section{Conclusions}

A classic tension between the intellectual property legal system and competition law recently has gained a sharp and tangible essence in moving from academic discussion to our everyday life. It has transformed into a fierce battle between competition authorities and pharmaceutical companies. The aim of the former is to protect competition to benefit consumers, using every possible tool (administrative, judicial, and political). The latter, meanwhile, claims the right to settle disputes with their competitors to protect their main corporate asset, by which they retain market share and secure their profits.

Both the FTC and the European Commission have defined a separate group of patent settlement agreements which combine certain provisions, such as restrictions on generic market entry and value transfer from a brand-name company to a generic company as a cause of their main concern treating such agreements as a violation of article 101 TFEU and Section 1 of the Sherman Act. Such concern was fuelled by certain indications that generic competition in the pharmaceutical industry is not working well. The competition authorities defined reverse payment agreements as one of the reasons for the delay of generic drugs' entry. Armed with provisions prohibiting restrictions on competition, the competition authorities have launched a campaign against these agreements. They claim violation of antitrust law if they find evidence of restriction on generic market entry along with value transfer from a brand-name to a generic company.

The U.S. courts facing this new type of patent-antitrust disputes have proven more cautious in their judgments. They carefully separate from the bundle of reverse payment agreements only truly anticompetitive agreements as per their view, based on the already settled patent and antitrust case law and new rules and approaches. However, the Third Court's maverick decision ${ }^{282}$ on 16 July 2012 undermined the comparatively settled case law since 2005, which relies mainly on the scope of patent doctrine. Firmly rejected previous practice, the Court declared all settlement agreements containing reverse payments to be presumably unlawful. This stance has led to two conflicting decisions by the two different circuits concerning the same agreements. Before the Third Circuit decision, the Supreme Court had never agreed to consider the matter. Thus, one may assume that this tension will probably serve as a sound ground for the Supreme Court to address this tension and construe the guidance to the courts as to how approach such agreements.

As the Court of Justice of the European Union has never considered this type of dispute, a U.S. Supreme Court decision on this matter may play a crucial role in establishing the relevant EU case law. As discussed above, however, the EU case law contains certain tests and approaches which may apply to the context of reverse payment agreements disputes. These judicial, administrative and political developments in the U.S. and the EU regarding the assessment of reverse payment agreements matter as the agreements are comparatively new: the overwhelming majority of jurisdictions have never

\footnotetext{
$281 \quad$ ibid, para 35.

$282 \quad$ In re K-Dur 3d Cir. 2012 (n 146).
} 
considered them. As soon as the practice settles in these jurisdictions, competition authorities in other jurisdictions are likely to follow that approach.

This article aimed to analyse current developments in these two jurisdictions and to define the current status of reverse payment agreements. It also aimed to extract provisions which most likely will raise the interest of competition authorities and which may lead to the recognition of an agreement as illegal and violative of antitrust law. Since pharmaceutical companies may risk being the target of competition authorities' investigations and subsequently litigation, such analysis pursued the practical goal of deepening understanding of what constitutes permitted behaviour for pharmaceutical companies when concluding this type of agreement to avoid antitrust liability.

Therefore, despite some difficulties in deducing the coherent line regarding reverse payment agreements after the Third Circuit's recent decision the following precautions would still seem sensible for those involved in negotiating settlements of patent disputes between pharmaceutical companies. ${ }^{283}$ First, it is advisable to avoid settlements which restrict generic entry in relation to products, periods or geographical areas outside the scope of the patents in question. ${ }^{284}$ It is likewise reasonable to avoid settlements which include direct payments from originator to generic company or agreements such as royalty-free licences, as they might be seen as equivalent to a direct payment. ${ }^{285}$

As a general recommendation, I would suggest the following. It could be cumbersome and complicated to produce one set of rules for such a complex issue, as each agreement may contain various provisions which distinguish it from a seemingly similar one. This variety forces competition authorities and courts to evaluate each agreement on a case-by-case basis. However, it may be useful to develop a specific set of guidelines based on the general principles which already exist in the U.S. case law, as well as in the EU. This consistency will help orientate the pharmaceutical industry and help both competition authorities and pharmaceutical companies conserve resources.

Another proposal relates to the recent decision to establish European Patent Court. As future patent settlement agreements will undoubtedly concern the European patents and disputes held by the EPC, to avoid the divergent approaches observed in the U.S. courts it may be reasonable to submit these disputes to the EPC jurisdiction. It would be worth considering the possibility of evaluation by the EPC of the patent validity on a prima facia basis. In refusing to decide this issue whilst reviewing the conformity of the reverse payment agreements, the U.S. courts appeal partially to the presumption of patent validity and partially to the lack of the necessary knowledge in reviewing it. ${ }^{286}$ As the EPC is a specialised patent court, it has the ability to decide on patent validity on a prima facie basis. This approach would eliminate all doubts as to the strength of the patent and would exclude all allegations of undeserved monopoly gained by the weak or invalid patent.

To conclude, though it may sound striking, however, in order to reconcile two legal systems (competition and patent) the result will be unavoidable: whilst patent is pending, the patent holder may exclude its competitors and settle the dispute, however anticompetitive it would not seem, unless this settlement exceeds the scope of the patent. Otherwise, the fragile balance could be injured, pushing the measures in one or another direction may damage or even destroy one of the systems. Overly strong patent protection will distort competition and ultimately harm consumers, who will suffer from the patent monopoly. The opposing situation, favouring competition over patent protection and expanding the boundaries of antitrust liability, will hamper industry innovation, also to the detriment of consumers.

\begin{tabular}{ll}
\hline 283 & Brankin (n 63) 28. \\
284 & ibid. \\
285 & ibid. \\
286 & Watson Pharms, 11th Cir. 2012 (n 130) 1315.
\end{tabular}

